\title{
Techno-Economic Assessment of a Standalone Hybrid System Using Various Solar Tracking Systems for Kalpeni Island, India
}

\author{
Vinoth John Prakash*(D) and Pradyumna Kumar Dhal \\ Vel Tech Rangarajan Dr. Sagunthala R\&D Institute of Science and Technology, Chennai 600062, India; \\ pradyumna.dhal@rediffmail.com \\ * Correspondence: vjp.tiglfg@gmail.com; Tel.: +91-962-935-3339
}

Citation: Prakash, V.J.; Dhal, P.K.

Techno-Economic Assessment of a Standalone Hybrid System Using Various Solar Tracking Systems for Kalpeni Island, India. Energies 2021, 14, 8533. https://doi.org/ $10.3390 /$ en 14248533

Academic Editor: Marco Pasetti

Received: 23 November 2021 Accepted: 14 December 2021 Published: 17 December 2021

Publisher's Note: MDPI stays neutral with regard to jurisdictional claims in published maps and institutional affiliations.

Copyright: (c) 2021 by the authors. Licensee MDPI, Basel, Switzerland. This article is an open access article distributed under the terms and conditions of the Creative Commons Attribution (CC BY) license (https:// creativecommons.org/licenses/by/ $4.0 /)$.

\begin{abstract}
Achieving electrification in an island considering less emission and levelized energy cost is a challenging goal on developing islands such as Kalpeni Island. This work exhibits the technoeconomic assessment of a standalone hybrid system to generate power to Kalpeni Island, India through sensitivity and optimization analysis using HOMER software. Various system configurations like solar/DG, wind/DG, solar/wind/DG, and solar/wind are analyzed based on cost and electrical parameters. Based on the optimization results, the best hybrid system is chosen for Kalpeni Island considering different solar tracking methods. Then, multi-year and sensitivity analysis are performed to analyze the effect of load growth, rising diesel price, rising battery minimum SOC, rising PVS derating, rising photovoltaic cell temperature, and changing inverter and rectifier efficiency. The system operated with a solar photovoltaic system (PVS) and diesel generator (DG) with a tracking system on a vertical axis (TSVA) shows the best optimization result compared to other hybrid configurations with a low levelized energy cost (LEC) of $0.222 \$ / \mathrm{kWh}$ and net present cost $\left(\mathrm{C}_{\mathrm{NP}}\right)$ of $\$ 448,269$ for the chosen location. The TSVA plays a vital role on power production in the system operated with solar and DG sources, which produces $9.77 \%$ more power compared to fixed system without tracking (FSWT). The total emission produced in the system operated with solar and diesel generator with TSVA is $88.2 \%$ less compared to an WT/DG configuration operated with FSWT.
\end{abstract}

Keywords: hybrid energy system; solar tracking system; levelized energy cost; total emission; net present cost; multi-year analysis; sensitivity analysis

\section{Introduction}

The electrical demand increases in proportion to an increase in population, residence, new industries, and the establishment of various commercial outlets. The increased use of various electrical appliances in household such as geysers, air conditioners, computers, etc. are inclined to raise the daily energy demand. The two types of generating power are stand-alone and the system with grid-connection. According to recent data from the Ministry of New and Renewable Energy, India, the capacity installed of conventional sources such as coal is $53.4 \%$, non-conventional sources are $36.2 \%$, and other sources are $10.4 \%$ in India [1]. Andaman and Nicobar Islands and Lakshadweep Island are two primary islands of India. Kalpeni Island is a part of Lakshadweep Island, which is considered to be the focus of this study. Furthermore, for electricity generation, renewable energy is the finest option for reducing global carbon emissions. The solar and wind power will satisfy the load demand at a low cost [2]. To satisfy the different load demands on Kalpeni Island, the system with different energy sources based on various tracking systems are analyzed based on levelized energy cost (LEC), loss of generation probability (LGP), expected energy not served (ENS), and emission. Thus, the techno economic assessment is carried out using the HOMER software.

The growth of remote energy production technologies is a useful alternative energy generation from non-conventional sources [3]. The microgrid is in charge of supplying 
power to the users that are considered. In most cases, a standalone microgrid is made up of non-conventional sources and diesel generators. Wind and solar power systems are frequently employed renewable sources in this difficult terrain. This is owing to the environmental impact while generating power. Emissions are produced by traditional sources such as power generation from fossil fuels. This polluted emission will have an impact on the people who live nearby as well as the overall environment. To combat the huge greenhouse effect, non-conventional sources have been implemented a lot over the last decade. In remote areas, instead of connecting the transmission line to the load, small microgrids are used [4]. The studies emphasize the benefits of microgrids. They all suggest that microgrids are dependable and effective [5-10]. The load demand is predicted to rise by $30 \%$ by the year 2030 while comparing the 2012 load level, owing primarily to population and economic expansion [11]. In this study, different analyses are conducted on Kalpeni Island in order to transform the scenario to a green environment at a cheap cost, less emission, and a higher reliability factor. The combination of numerous clean energy technologies can improve system performance without requiring the integration of a backup power system [12]. In practice, the location of solar systems installation should take advantage of a variety of circumstances that will have an impact on the system [13]. The sun's light and heat are a preferable type of renewable, pure, and unlimited energy. In addition, it is generally believed to be the preferable source of energy [14]. A standalone solar-wind with a battery becomes an interrupted system with complicated evolution and several restrictions [15]. The non-conventional sources are becoming increasingly popular in urban and rural areas [16]. The hybrid system consisting of wind and solar will not match with hourly or timely load demand [17]. For a residential load demand, methodology was developed [18]. It is simple to control the DC microgrid. The intermittent nature of renewable sources can be avoided when some microgrids are available in operation [19]. The main disadvantage of a standalone system that uses solar and wind energy is power variance, which results in discontinuous power delivery and causes problems if a stable and consistent supply is required. As a result, standalone hybrid systems with diesel generator could be used to solve such issues [20].

The renewable energy source is the best solution to reduce emission when a system is operated with renewable and diesel generators in islands. The total number of households on Kalpeni Island is 934 [21]. In this study, estimated load consumption data for 25 households, 3 grocery shops and 12 LED street lights on Kalpeni Island are considered to investigate the performance of a hybrid non-conventional system with a diesel generator. This study focuses mainly on solar/wind/DG sources with different tracking systems. The comparative analysis for the system operating with different tracking systems are conducted to understand the use of solar trackers. The hybrid energy system with solar tracking techniques for Kalpeni Island are not investigated in previous research. The novelty of this work helps the researcher to identify the operation of different sources consisting of solar trackers with less cost on an island. The tracking systems helps to operate solar panels in an effective manner with more power production when compared to traditional solar panels. The reliability indices like expected energy not served (ENS) and loss of generation probability (LGP) are the main challenges of a hybrid system operating on an island. When the ENS/LGP is high, the system will not be able to supply sufficient power to Kalpeni Island. This problem can be solved by incorporating feasible sources operating in a suitable time period with low cost and less emission. The system is simulated using HOMER software since it is one of the best optimization tools in the decade. The HOMER is the most widely used software package among several since it does optimization and sensitivity analysis more efficiently in analyzing the different configurations of the system [22]. The rest of the article is organized as follows: Section 2 shows the detailed survey of hybrid non-conventional sources based on reliability, emission, cost factors, and a survey on comparative study of various tracking systems. In Section 3, the description of the proposed site, detailed load profile, environmental data of the chosen site, specification and modelling of various configurations in hybrid systems are discussed. 
The optimization results of different hybrid configurations with various solar trackers and the best system based on a solar tracking technique are analyzed in Section 4. Moreover, multi-year and sensitivity analysis of various parameters was also performed in this section. The conclusions are given in Section 5.

\section{Literature Review}

\subsection{Survey of the Hybrid Renewable Energy System}

In recent days, a hybrid system using a solar photovoltaic system (PVS) and a wind energy system has been evolving for standalone applications. Several studies on microgrid systems operating in standalone mode to build a green environment are performed. When using solar or wind power, the battery plays a vital role in the microgrid system. When there is a poor environmental condition and the battery state of charge is less than the minimal value, the diesel generator can be employed as a backup source. Because solar and wind systems work completely randomly in nature, the microgrid must operate in such a way that the load demand should satisfy for each instant of time. Tribioli and Cozzolino [23] investigated, for an isolated system, a photovoltaic microgrid with different storage techniques was constructed and the performance of a power management plan was tested using HOMER Energy software. Cetinbas et al. [24] concluded that, for the given load pattern, a PV power supply of $2.500 \mathrm{MW}$, two batteries of $110 \mathrm{kWh}$ capacity, and a diesel power generator of 2.100 MW were found to be the best solution. The suggested study investigated the impact of PV module degradation, rising demands, system disruptions and rising diesel fuel prices. Garg et al. [25] examined the solar output variation, operation of diesel generator and battery output for different cases in the combined energy system. Akinyele et al. [26] presented a proposed microgrid system with a diesel generator which can offer full energy for households in the selected sites, according to the results. Al-Ammar et al. [27] reveal that a hybrid source with wind/PVS is the suitable option for the particular location of the study, and the effective system component sizing is also evaluated with $\$ 28.620 \mathrm{~K}$ net present cost $\left(\mathrm{C}_{\mathrm{NP}}\right)$ and $0.311 \$ / \mathrm{kWh}$ levelized energy cost (LEC), resulting in a cost reduction more than $80 \%$ and a $100 \%$ reduction in harmful pollutants while meeting $100 \%$ power requirements with 67.3 percent surplus power. Vera et al. [28] study the detailed literature on an energy management microgrid system with battery storage. The correct direction in suitable modelling for batteries was also included in the literature. Chambon et al. [29] presented PVS-biomass or PVS-diesel hybrid systems which provided the maximum reliability and the lowest cost for standalone electricity. Solar photovoltaic systems were determined to offer the least levelized energy cost (LEC) of $0.20 \$ / \mathrm{kWh}$ among standalone choices for a $4 \%$ annual capacity deficit. The reliability is an important parameter in calculating the microgrid system performance. Many works of literature were conducted for assessing the reliability in a microgrid energy system [30-33]. Priyadharshini et al. [34] worked on the objective to satisfy the consumers by generating continuous power using solar and wind systems at minimum cost. Ali et al. [35] investigated the simulation which demonstrates that the hybrid micro may reduce a carbon footprint by over $90 \%$ when compared to the traditional system, according to the techno-economic framework. Ahmad et al. [36] developed the algorithm for feasible operation of the proposed system. The objective of the work is to run a microgrid system with optimal configuration. A proper microgrid design requires a thorough analysis of the electricity system. Lee et al. [37] suggested a method that yields an optimal microgrid configuration that meets the design goal in terms of financial efficiency and power system performance restrictions. Alturki et al. [38] suggested a hybrid photovoltaic/biomass/wind/pump-hydro system would be perfect for a tiny village, local hospital, education, and industrial sites. The suggested system's economic viability and sustainable development are also in accordance with the international energy market. Hinokuma et al. [39] conducted a sensitive analysis to determine the effectiveness of the suggested system using 2030 costs for non-conventional energy technologies. The study indicates that lowering the commercial cost of solar panels, which is the major unit in the 
microgrid system, is critical for lowering the cost of electricity. Riou et al. [40] suggested that boosting reliability of the microgrid at the preliminary level can be done for the less amount of money. Fathy et al. [41] conducted an analysis of a hybrid renewable system with a diesel generator for determining reliability indices like loss of generation probability (LGP) index. Yu et al. [42] summarized about reduction of carbon emission in a year, load profile alignment by considering cost parameter, and performance of battery storage optimum operation. To assess the standalone system cost, various literature works have been reviewed [43-47]. Rashid et al. [48] investigated different configurations in microgrid system design using HOMER. The levelized cost are compared for different scenarios. Table 1 shows the survey of a hybrid system using HOMER. The different sources like photovoltaic system (PVS), wind turbine (WT), fuel cell (FC), diesel generator (DG), hydro and tidal operated to analyze the reliability and cost of energy. The battery operated in the system when the system operated with renewable sources.

Table 1. Survey of the hybrid system using HOMER.

\begin{tabular}{|c|c|c|c|c|}
\hline Operating Mode & System Considered & Parmeter & Details & Ref. \\
\hline Stand-alone & PVS/WT/FC/DG & LEC & $\begin{array}{l}\text { The objective of this study is to create a stand-alone } \\
\text { microgrid with implementation in rural island and } \\
\text { rural electricity. }\end{array}$ & [49] \\
\hline Stand-alone & $\begin{array}{l}\text { PVS/DG, PVS alone, } \\
\text { PVS/WT, DG alone }\end{array}$ & LEC & $\begin{array}{c}\text { The survey shows that the PVS/diesel/battery can } \\
\text { provide adequate energy to the island of Ethiopia } \\
\text { throughout the duration of the work. }\end{array}$ & [50] \\
\hline Grid connected & WT/FC & Emission, $\mathrm{C}_{\mathrm{NP}}$ & $\begin{array}{l}\text { The system's total income and return are calculated } \\
\text { and examined for saving energy, decarbonization, } \\
\text { and green infrastructure. }\end{array}$ & [51] \\
\hline Stand-alone & PVS/WT/DG & LPSP, LEC & $\begin{array}{c}\text { The result determined based on reliability, cost, } \\
\text { technical feasibility, and ecological responsibility } \\
\text { are all important factors to consider }\end{array}$ & [52] \\
\hline Stand-alone & PVS/FC & $\mathrm{LEC}, \mathrm{C}_{\mathrm{NP}}$ & $\begin{array}{l}\text { The result shows that the system operate without } \\
\text { emission and the reliability index like loss of } \\
\text { generation probability (LGP) is } 0.05 \% \text { and levelized } \\
\text { energy cost (LEC) is } 0.22 \$ / \mathrm{kWh}\end{array}$ & [53] \\
\hline Stand-alone & $\begin{array}{l}\text { WT/DG/SPV, } \\
\text { WT/PVS/DG, } \\
\text { WT/PVS }\end{array}$ & $\mathrm{LEC}, \mathrm{C}_{\mathrm{NP}}$ & $\begin{array}{c}\text { The system operated with } 0 \% \text { excess power flow } \\
\text { and the levelized energy cost as } 0.24 \text { euro in } \\
\text { the island }\end{array}$ & [54] \\
\hline Stand-alone & $\begin{array}{l}\text { DG, PVS/WT, } \\
\text { PVS/WT/FC }\end{array}$ & LEC, LPSP & $\begin{array}{l}\text { The cost and reliability factor for the different } \\
\text { system configuration are analysed and compared }\end{array}$ & [55] \\
\hline Grid-connected & $\begin{array}{c}\text { WT/tidal, } \\
\text { WT/tidal/DG }\end{array}$ & LEC, $\mathrm{C}_{\mathrm{NP}}$, emission & $\begin{array}{l}\text { The wind turbine is operated } 90 \% \text { annual for the } \\
\text { site considered }\end{array}$ & [56] \\
\hline Grid-connected & PVS/Hydro & LEC, emission & $\begin{array}{c}\text { The system operated with low cost and emission } \\
\text { and higher degree of renewables }\end{array}$ & [57] \\
\hline Stand-alone & $\begin{array}{l}\text { PVS/WT/DG, } \\
\text { PVS/DG, WT/DG, } \\
\text { PVS/WT, PVS alone, } \\
\text { WT alone }\end{array}$ & LEC, emission, $\mathrm{C}_{\mathrm{NP}}$ & $\begin{array}{l}\text { The levelized energy cost analysed according to the } \\
\text { different level of renewable \%. The system with } \\
\text { PVS/wind/DG has less emission compared to the } \\
\text { system only operated with diesel generator }\end{array}$ & [58] \\
\hline Stand-alone & PVS/WT/DG & LEC, emission, $\mathrm{C}_{\mathrm{NP}}$ & $\begin{array}{l}\text { The sensitivity analysis is performed for variation } \\
\text { in temperature to know about the effect of levelized } \\
\text { energy cost (LEC) and net present cost }\left(C_{N P}\right)\end{array}$ & [59] \\
\hline
\end{tabular}

Iqbal et al. [60] designed a microgrid based on institutional level and determined the best solution for the site considered. The capacity of storage element changes the levelized energy cost and net present cost. Sadat et al. [61] proposed a new strategy for the price in Iran while designing a microgrid system using HOMER. Rousis et al. [62] presented a sensitivity analysis for different values of diesel prices in the hybrid microgrid system. Then, a sensitivity analysis was performed for different solar radiation using HOMER. Olatomiwa et al. [63] performed a sensitivity analysis for different wind speed and diesel price in the microgrid system. Sanwar et al. [64] investigated the electricity 
generation in Bangladesh for a standalone system using HOMER software. Different hybrid system configurations are examined for capacity cost, levelized energy cost, net present cost and production of wind power. Xia et al. [65] performed a sensitivity assessment for the influence of $10 \%$ variations in speed of wind, radiation from the sun, temperature and flow rate on yearly electricity output, unmet load demand, levelized energy cost (LEC) and net present cost $\left(\mathrm{C}_{\mathrm{NP}}\right)$. A remote community consists of fifteen families has been chosen as the relevant example. Rezaei et al. [66] examined the uncertainty analysis for cost. The result of uncertainty operation shows that there is a variation in discount price. Sanjay et al. [67] proposed a microgrid system with less energy cost for agricultural application. Shahzad et al. [68] conducted a study on a microgrid using HOMER for cost reduction. To reflect the simulation result, the surface plot for levelized energy cost plotted with net present cost. Aziz et al. [69] investigated the results for a renewable system based on different dispatch strategies like combined, load following, and cycle charging strategy. The result shows that levelized energy cost is $0.21 \$ / \mathrm{kWh}$ for combined strategy, which is less compared to the other two dispatch strategies. Beitelmal et al. [70] analyzed four different hybrid microgrid configurations for the proposed and existing case study for power supply. The result shows that the levelized energy cost and net present cost is less in photovoltaic battery energy sources while comparing the other three hybrid configurations. Chauhan et al. [71] examined the optimization model for the microgrid system with different reliability and cost constraints. The levelized energy cost is less in $0.225 \% / \mathrm{kWh}$ in the configuration like three diesel generators, one photovoltaic system and one battery. Yadav et al. [72] discusses about transfer of power to the load in various environmental conditions. Thirunavukkarasu et al. [73] evaluated three different parameters in a microgrid system. The three parameters are reliability, levelized energy cost and emission. The objective is to achieve $0 \%$ unmet load with less levelized energy cost (LEC). It was found that the levelized energy cost for photovoltaic system (PVS) with a diesel generator (DG) is $0.319 \$ / \mathrm{kWh}$.

\subsection{Survey of Various PV Tracking Systems}

The different tracking systems like fixed system without tracking (FSWT), tracking system on a horizonal axis (TSHA), tracking system on a vertical axis (TSVA) and tracking system on a dual axis (TSDA) are studied in various works of literature to understand the performance of various solar trackers in the system as shown in Table 2. Ruelas et al. [74] proposed a methodology for tracking PVS based on different points of tracking. Comparing the traditional tracking system, the proposed tracking method collected $24 \%$ more energy. González-Peña et al. [75] evaluated the prediction of PVS power production using different software tools. When there is a big storm, the PVS trackers' increased error rate, and a safe location decreased the quantity of electricity generated. Seme et al. [76] reviewed the various tracking systems used in PVS. A multi axis and tracking system with one axis collected $22 \%$ to $56 \%$ more energy compared to the ideal tracking system. Kuttybay et al. [77] proposed a new tracking system with the efficiency of $57.4 \%$ compared to the existing tracking methods. The one axis tracking system is the better way to generate power using PVS when the PVS operated with less capacity [78-81]. Babatunde et al. [82] compared different tracking system with and without coefficient of temperature. Sá Campos et al. [83] proposed a model of rotation of a tracking system on a single axis. As a consequence, the efficiency in comparison to tracking continuously was validated, exposing a loss of roughly $0.73 \%$ in the position seven approach, which could not be verified easily in the presence of errors, particularly on a cloudy weather day when such a gap can be lower. 
Table 2. Review of various Tracking systems (TS) used in PVS.

\begin{tabular}{|c|c|c|}
\hline TS & Details & Ref. \\
\hline TSDA & $\begin{array}{l}\text { Investigated the planning of solar tracker cost of investment } \\
\text { and compared the TSDA with FSWT. The result shows that } \\
\text { the tracking system on dual axis (TSDA) collected } 35.6 \% \text { and } \\
44.7 \% \text { more energy during the 1st and } 2 \text { nd year compared to a } \\
\text { fixed system without tracking (FSWT). }\end{array}$ & [84] \\
\hline TSDA & $\begin{array}{l}\text { Implemented a simple model of multi axis tracking PVS. The } \\
\text { proposed model of two axis PVS collected } 36.2 \% \text { more energy } \\
\text { than the traditional fixed tracking model of PVS. }\end{array}$ & [85] \\
\hline TSDA & $\begin{array}{l}\text { Reviewed the tracking system on dual axis and determine the } \\
\text { efficiency which is ranging from } 35 \% \text { to } 43 \% \text {. }\end{array}$ & [86] \\
\hline Single axis TS & $\begin{array}{l}\text { Presented the results of power generation evaluations of } \\
\text { bifacial PVS with fixed angle and tracking system on a } \\
\text { horizontal axis (TSHA) in contrast to their mono facial } \\
\text { equivalents. Furthermore, the projected information is } \\
\text { compared to the existing results. }\end{array}$ & [87] \\
\hline TSVA, TSHA, TSDA & $\begin{array}{l}\text { The result shows that tracking system on a vertical axis } \\
\text { (TSVA) produces less emission while compared with a two } \\
\text { axis tracking system }\end{array}$ & [88] \\
\hline Single axis TS & $\begin{array}{c}\text { Various orientations of a single axis tracking system are } \\
\text { studied for each day }\end{array}$ & [89] \\
\hline Single axis and TSDA & $\begin{array}{c}\text { The result shows that } 27 \text { to } 30 \% \text { and } 30 \text { to } 34 \% \text { more power } \\
\text { produced using single and dual axis tracking systems } \\
\text { respectively when compared to FSWT }\end{array}$ & [90] \\
\hline Single axis and TSDA & $\begin{array}{l}\text { The result shows that in a single and tracking system on dual } \\
\text { axis (TSDA), the efficiency of tracking are } 99.1 \text { and } 89.2 \%\end{array}$ & [91] \\
\hline TSDA & $\begin{array}{l}\text { In the proposed method of tracking sun position, the result } \\
\text { shows that } 28 \% \text { to } 43 \% \text { energy from solar captured }\end{array}$ & [92] \\
\hline TSVA, TSHA, TSDA & $\begin{array}{l}\text { The result shows that } 28.8 \% \text { extra power is generated from } \\
\text { the photovoltaic system compared to an ideal tracking system }\end{array}$ & [93] \\
\hline Single axis and TSDA & $\begin{array}{l}\text { The efficiency analysis comparison of single and two axis } \\
\text { tracking system are obtained in the result }\end{array}$ & [94] \\
\hline
\end{tabular}

Pelaez et al. [95] investigated a model of a tracking system with one axis in the bifacial mode of solar panels. The energy increases by $4-15 \%$ in this mode of operation. The tracker is analyzed for different conditions of clouds. Rodriguez-Gallegos et al. [96] examined the two different algorithms, namely sun tracking and best inclination tracking. The result concluded that best inclination tracking has good results compared to the sun tracking algorithm. Saeedi et al. [97] presented the advantage of using a tracking system on a dual axis (TSDA) compared to traditional tracking systems based on solar photovoltaic power output. Zaghba et al. [98] demonstrated the system efficiency for two axis and inclined fixed systems without tracking (FSWT). The performance result shows that the tracking system on a dual axis collects more power compared to the inclined fixed system without tracking.

\section{Methodology}

A thorough assessment of any non-conventional project requires the use of relevant factors in the chosen location to guarantee that the actual performance of various situations can be effectively examined.

\subsection{Site Description}

Kalpeni Island is located $287 \mathrm{~km}$ west from the city of Kochi, India in the Arabian sea as shown in Figure 1. This island is one among the islands of Lakshadweep. The geographical location of this island is $10^{\circ} 4.0^{\prime} \mathrm{N}, 73^{\circ} 38.7^{\prime} \mathrm{E}$. As per the data of the last census, 4419 people are living in this island. 


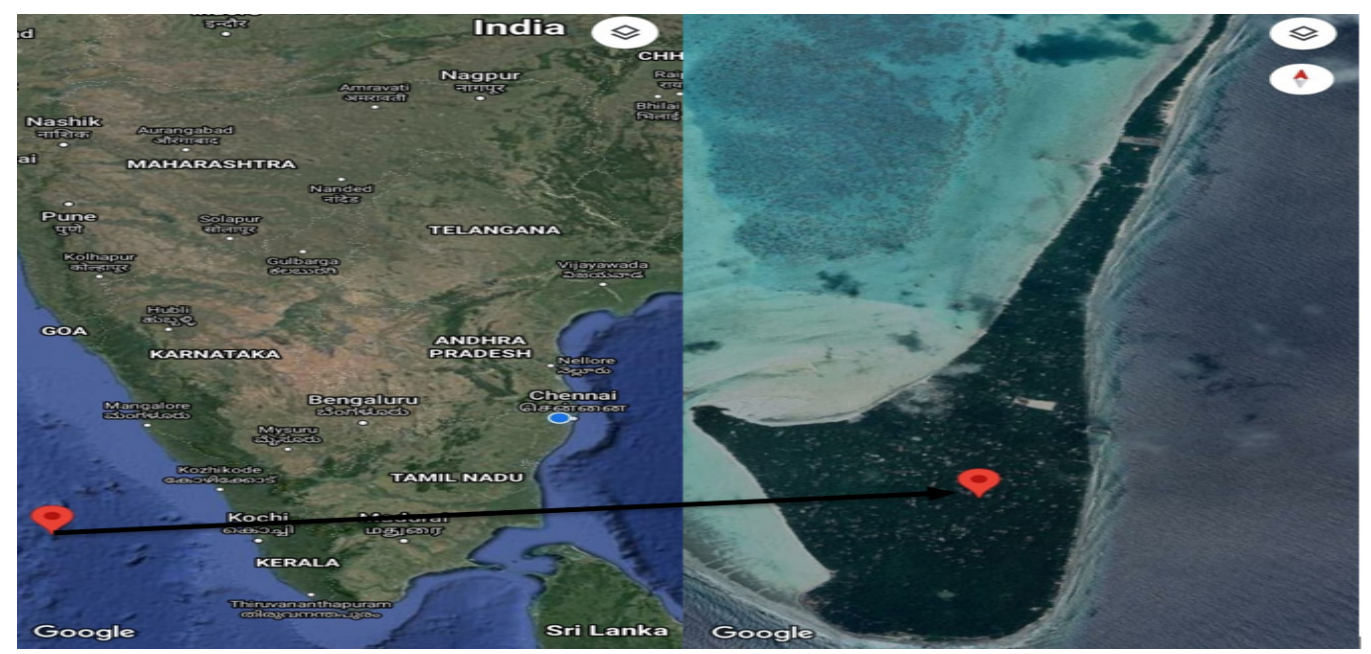

Figure 1. Location of Kalpeni Island, India (satellite view).

\subsection{Load Profile}

The estimated average daily load consumption for 1 household and electric load-2 throughout a year are shown in Table 3 . The electric load- 2 consists of 1 commercial load (1 grocery shop) and 12 LED street lights. Consider the Kalpeni Island as consisting of 25 households, 3 grocery shops and 12 LED street lights for this study and the required data for this are developed from Table 3.

Table 3. Average daily consumption for domestic load and electric load-2 during summer and winter seasons of Kalpeni Island.

\begin{tabular}{|c|c|c|c|c|c|c|c|c|c|c|c|}
\hline \multicolumn{6}{|c|}{ Domestic Load (1 Household) } & \multicolumn{6}{|c|}{ Electric Load-2 (12 Street Light and 1 Grocery Shop) } \\
\hline \multirow{2}{*}{ Type of Load } & \multirow{2}{*}{$\mathrm{PL}_{\mathrm{D}}(\mathrm{W})$} & \multicolumn{2}{|c|}{ Summer } & \multicolumn{2}{|c|}{ Winter } & \multirow{2}{*}{ Type of Load } & \multirow{2}{*}{$\mathrm{PL}_{\mathrm{D}}(\mathrm{W})$} & \multicolumn{2}{|c|}{ Summer } & \multicolumn{2}{|c|}{ Winter } \\
\hline & & Hrs & Wh & Hrs & Wh & & & Hrs & Wh & Hrs & Wh \\
\hline \multirow{4}{*}{$\begin{array}{c}\text { Ceiling fan } \\
\text { (3 Nos) } \\
\text { Air conditioner } \\
\text { Laptop } \\
\text { LED TV }\end{array}$} & $\begin{array}{l}60 \mathrm{~W} \\
\text { (each) }\end{array}$ & $12,4,4$ & 1200 & $12,4,4$ & 1200 & \multirow{2}{*}{$\begin{array}{l}\text { LED street light } \\
\quad(12 \text { Nos })\end{array}$} & \multirow{2}{*}{$100 \mathrm{~W}$ (each) } & \multirow{2}{*}{$12 * 13$} & \multirow{2}{*}{15,600} & \multirow{2}{*}{$12 * 13.5$} & \multirow{2}{*}{16,200} \\
\hline & 1510 & 5 & 7550 & 0.1 & 151 & & & & & & \\
\hline & 60 & 1 & 60 & 1 & 60 & Refrigerator-1 & 550 & 24 & 13,200 & 24 & 13,200 \\
\hline & $\begin{array}{c}40 \\
2000\end{array}$ & $\begin{array}{c}7 \\
0.3\end{array}$ & $\begin{array}{l}280 \\
600\end{array}$ & $\begin{array}{c}7 \\
0.6\end{array}$ & $\begin{array}{l}280 \\
1200\end{array}$ & Refrigerator-2 & 290 & 24 & 6960 & 24 & 6960 \\
\hline Grinder & 150 & 0.5 & 75 & 0.5 & 75 & \multirow{2}{*}{$\begin{array}{l}\text { Ceiling fan } \\
\text { (2 Nos) }\end{array}$} & \multirow{2}{*}{$60 \mathrm{~W}$ (each) } & \multirow[t]{2}{*}{15,15} & \multirow{2}{*}{1800} & \multirow[t]{2}{*}{15,15} & \multirow[t]{2}{*}{1800} \\
\hline $\begin{array}{l}\text { Washing } \\
\text { machine }\end{array}$ & 500 & 0.5 & 250 & 0.5 & 250 & & & & & & \\
\hline \multirow{2}{*}{$\begin{array}{l}\text { machine } \\
\text { Electric motor } \\
\text { Mobile } \\
\text { charging } \\
\text { (3 Nos) }\end{array}$} & 1511 & 0.5 & 755.5 & 0.5 & 755.5 & \multirow{2}{*}{$\begin{array}{l}\text { LED tube light } \\
\text { (5 Nos) }\end{array}$} & \multirow[t]{2}{*}{$20 \mathrm{~W}$ (each) } & \multirow[t]{2}{*}{$4,4,0,0$} & \multirow[t]{2}{*}{160} & \multirow[t]{2}{*}{$5,5,1,1$} & \multirow[t]{2}{*}{240} \\
\hline & $\begin{array}{c}5 \mathrm{~W} \\
\text { (each) }\end{array}$ & $1,1,1$ & 15 & $1,1,1$ & 15 & & & & & & \\
\hline \multirow{2}{*}{$\begin{array}{l}\text { LED tube light } \\
\text { (5 Nos) }\end{array}$} & \multirow{2}{*}{$\begin{array}{l}20 \mathrm{~W} \\
\text { (each) }\end{array}$} & \multirow{2}{*}{$\begin{array}{l}5,2,1 \\
0.1,0.1\end{array}$} & \multirow{2}{*}{164} & \multirow{2}{*}{$\begin{array}{c}\text { 6, 2.5, } 2 \\
0.1,0.1\end{array}$} & \multirow{2}{*}{214} & & Domestic & ad (1 hou & hold) & & \\
\hline & & & & & & Iron box & 1000 & 0.1 & 100 & 0.1 & 100 \\
\hline $\begin{array}{l}\text { LED bulb } \\
\text { (3 Nos) }\end{array}$ & $\begin{array}{c}9 \mathrm{~W} \\
\text { (each) }\end{array}$ & $0.1,4,0.1$ & 37.8 & $0.1,5,0.1$ & 46.8 & Refrigerator & 250 & 24 & 6000 & 24 & 6000 \\
\hline
\end{tabular}

Each street consists of a minimum of 8 households, 1 grocery shop and 4 street lights. Six months (March-August) and the next six months (September-February) are considered as summer and winter seasons, respectively. These load data are imported into the HOMER software. In HOMER software, the random variability values are given to achieve the reality of the load profile. For domestic load, random variability for time step is considered as $15 \%$ and day to day as $10 \%$. Similarly, for electric load-2, load time step is considered as $20 \%$ and day to day as 5\%. From Table 3, the hourly data for $24 \mathrm{~h}$ are given based on the following details. During the summer season, the air conditioner is used from 12:00 a.m. to 3:00 a.m. The refrigerator is operating for the whole $24 \mathrm{~h}$. Thus, from 12.00 a.m. to 3.00 a.m., load increases since both the air conditioner and refrigerator are switched on. It decreases after 3.00 a.m. once the air conditioner is auto- switched off. On an average day, the ceiling 
fan is considered to be operational for at least 20 h. At 7.00 a.m., most households use a water geyser which consumes $2000 \mathrm{~W}$ power, an iron box for $6 \mathrm{mts}$ which consumes 1000 watts and $1.5 \mathrm{HP}$ electric motor for pumping water to the tank. From 8.00 a.m. to 6.00 p.m., children will be off to schools and colleges and adults will be off to work. Within this time, LED Television, washing machine and grinder will be used by people at home. From 6.00 p.m. to 9.00 p.m., laptop and mobile charging, LED tube lights and bulbs are used. From 10.00 p.m. to 12.00 a.m., the air-conditioner was switched ON. Now, during the winter season, the use of an air conditioner decreases significantly while the use of a water geyser increases significantly at 7.00 a.m. In electric load-2, the street lights are operated from 6.00 p.m. to 6.00 a.m. with the extension of 30 mins during winter. In three grocery shops, the refrigerators are operational for $24 \mathrm{~h}$, the ceiling fans are operating from 7.00 a.m. to 10.00 p.m. and the LED tube lights are operating from 6.00 p.m. to 10.00 p.m. Thus, there is a constant load demand most of the time in electric load-2.

Figure 2 shows the monthly mean scaled load profile for January to December. Figure 2 shows the monthly mean scaled load consumption of 25 households, 3 grocery shops and 12 LED street lights. The maximum load, minimum load, daily average maximum, daily average minimum and mean load are shown for each month of a year. The maximum load is $74.81 \mathrm{~kW}$ during the month of June and the minimum load is $55.06 \mathrm{~kW}$ during the month of October. Since June is summer for Kalpeni Island, there is maximum load demand in this month due to usage of additional appliances by each household, but October is winter, and there is a minimum load demand due to non-usage of different appliances, in particular, the air conditioners. The daily average maximum load, daily average minimum load, and average load vary every month in a year as shown in Figure 2. The scaled average energy consumption, average load and peak load for domestic load is $346.43 \mathrm{kWh} /$ day, $14.43 \mathrm{~kW}$, and $68.99 \mathrm{~kW}$, respectively, and, for electric load-2, it is $80.87 \mathrm{kWh} /$ day, $3.37 \mathrm{~kW}$ and $7.44 \mathrm{~kW}$, respectively.

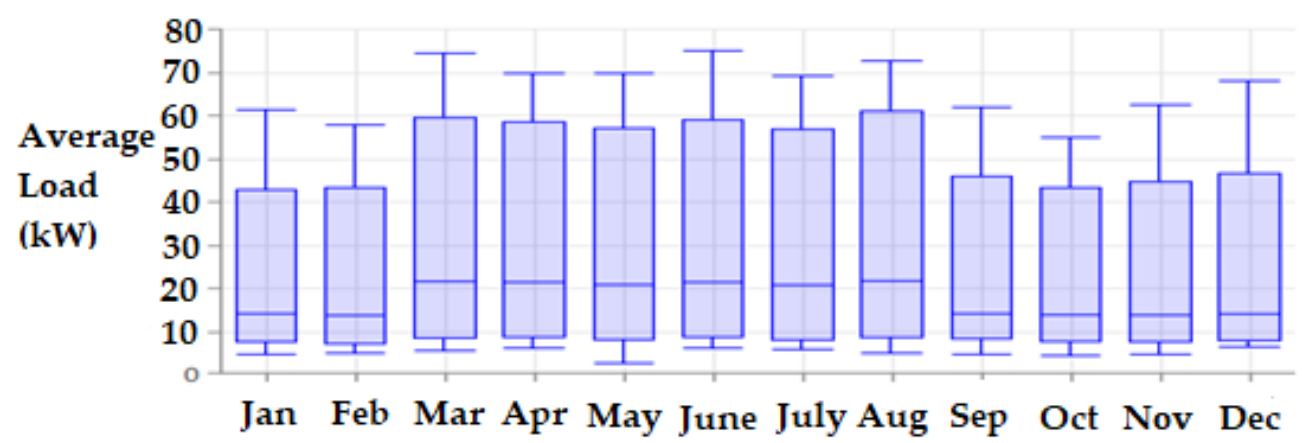

Figure 2. Monthly average scaled load profile for January-December.

\subsection{Solar Radiation and Speed of Wind}

The longitude, latitude data of Kalpeni Island is given to HOMER software for downloading the average speed of wind and solar radiation resource. The monthly average speed of wind and solar radiation data in a year are graphically represented in Figure $3 a, b$. The annual average wind speed and solar radiation for the selected site are $5.38 \mathrm{~m} / \mathrm{s}$ and $5.68 \mathrm{kWh} / \mathrm{m}^{2} /$ day, respectively. The average solar radiation is higher during the month of March at $6.920 \mathrm{kWh} / \mathrm{m}^{2} /$ day and lower during June at $4.680 \mathrm{kWh} / \mathrm{m}^{2} /$ day as shown in Figure $3 \mathrm{a}$. The sky is clear during November-May when compared with June-October. The average speed of wind is higher during the month of June at $8.930 \mathrm{~m} / \mathrm{s}$ and lower during the month of February at $3.480 \mathrm{~m} / \mathrm{s}$ as graphically represented in Figure $3 \mathrm{~b}$. 


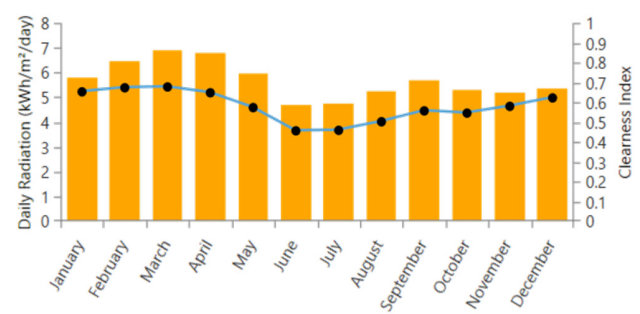

(a)

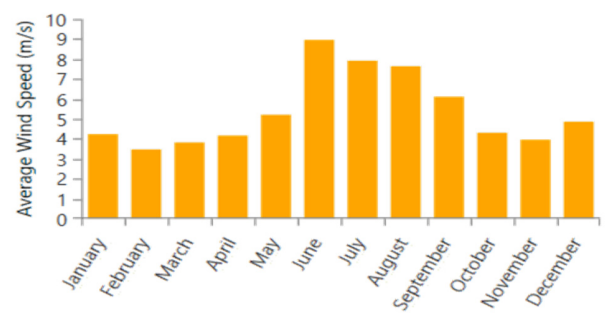

(b)

Figure 3. (a) Average solar radiation; (b) average speed of wind.

\subsection{Hybrid System Block Diagram for Different Configurations}

The schematic diagram of the hybrid system in various configurations such as PVS/DG, WT/DG, PVS/WT and PVS/WT/DG are given in Figure 4. To evaluate the result accurately, the system is studied under various configurations. This system is developed to satisfy the load demand of Kalpeni Island.

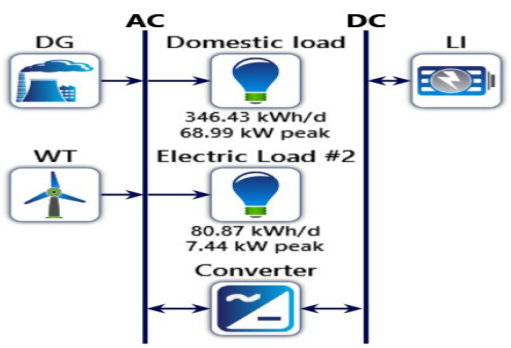

(b)

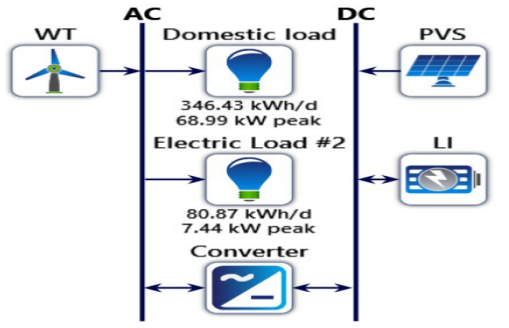

(c)

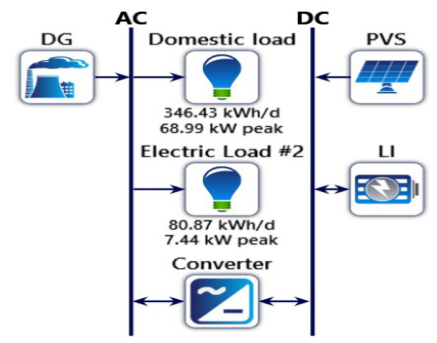

(a)

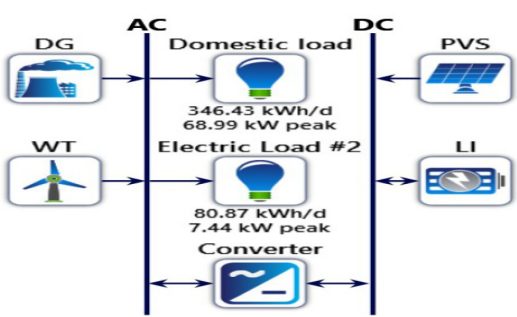

(d)

Figure 4. Schematic diagram of hybrid system (a) PVS/DG; (b) WT/DG; (c) PVS/WT; (d) PVS/WT/DG.

The domestic load refers to the households and the electric load-2 refers to the grocery shops and street lights. The diesel generator (DG) and wind turbine (WT) are linked to the AC bus and solar photovoltaic system (PVS) and Lithium ion (LI) battery are linked to the DC bus for supplying power to Kalpeni Island. When there are excess power flows from PVS and WT, the battery gets charged. The battery is discharged when there is insufficient solar radiation and wind speed for a time ' $t$ ' to satisfy AC load demand through the inverter. For each configuration, the lithium-ion battery is included to overcome the power shortage due to environmental conditions. The diesel generator is also used for supplying power to 
the island as a backup source when the output of renewable energies is insufficient to fulfill the AC load demand. The converter is used either as an inverter or a rectifier between $\mathrm{AC}$ and DC bus. The converter converts Direct Current (DC) to alternating current (AC) during inverter operation and from alternating current (AC) to direct current (DC) during rectifier operation.

Table 4 shows the specification of solar PVS, wind turbine, diesel generator (DG), converter, battery and other parameter inputs given to HOMER software. The replacement cost, capital cost, operation and maintenance $(\mathrm{O} \& \mathrm{M})$ cost for each component in the hybrid system are given in Table 4. Based on the inputs given to HOMER software, the optimization results obtained with the best optimum value based on less levelized energy cost (LEC).

Table 4. Specification of the hybrid system.

\begin{tabular}{|c|c|c|c|c|c|}
\hline Components & Description & Specification & Components & Description & Specification \\
\hline \multirow{3}{*}{ Solar PVS [69] } & $\begin{array}{l}\text { Capacity } \\
\text { Capital cost }\end{array}$ & $\begin{array}{c}1 \mathrm{~kW} \\
640 \$ / \mathrm{kW}\end{array}$ & \multirow{3}{*}{ Converter [23] } & Capacity & $1 \mathrm{~kW}$ \\
\hline & Replacement cost & $640 \$ / \mathrm{kW}$ & & Efficiency & $96 \%$ \\
\hline & $\begin{array}{l}\text { O\&M cost } \\
\text { Lifetime }\end{array}$ & $\begin{array}{l}10 \$ / \text { year } \\
25 \text { years }\end{array}$ & & Capital cost & $300 \$ / \mathrm{kW}$ \\
\hline \multirow{5}{*}{ Wind turbine [65] } & & & \multirow{5}{*}{ Converter [23] } & \multirow[b]{2}{*}{ Replacement cost } & \multirow[b]{2}{*}{$300 \$ / \mathrm{kW}$} \\
\hline & $\begin{array}{l}\text { Capacity } \\
\text { Hub height }\end{array}$ & $\begin{array}{l}1 \mathrm{~kW} \\
16 \mathrm{~m}\end{array}$ & & & \\
\hline & Capital cost & $2000 \$ / \mathrm{kW}$ & & \multirow{2}{*}{ O\&M cost } & \multirow{2}{*}{0 \$/year } \\
\hline & Replacement cost & $1200 \$ / \mathrm{kW}$ & & & \\
\hline & $\begin{array}{l}\text { O\&M cost } \\
\text { Lifetime }\end{array}$ & $\begin{array}{l}100 \$ / \text { year } \\
20 \text { years }\end{array}$ & & Lifetime & 15 years \\
\hline \multirow{9}{*}{ Li-Ion battery [99] } & Nominal voltage & $6 \mathrm{~V}$ & \multirow{6}{*}{$\begin{array}{c}\text { Diesel generator } \\
\text { (Autosize) [69] }\end{array}$} & $\begin{array}{l}\text { Minimum load } \\
\text { ratio }\end{array}$ & $25 \%$ \\
\hline & $\begin{array}{l}\text { Nominal } \\
\text { capacity }\end{array}$ & $1 \mathrm{kWh} / 167 \mathrm{Ah}$ & & Fuel price & $1 \$ /$ liter \\
\hline & $\begin{array}{l}\text { Roundtrip } \\
\text { efficiency }\end{array}$ & $90 \%$ & & Capital cost & $220 \$ / \mathrm{kW}$ \\
\hline & $\mathrm{SOC}_{\min }$ & $20 \%$ & & Replacement cost & $200 \$ / \mathrm{kW}$ \\
\hline & $\mathrm{SOC}_{\max }$ & $100 \%$ & & O\&M cost & $\begin{array}{c}0.020 \\
\text { \$/operating hrs }\end{array}$ \\
\hline & Capital cost & $140 \$$ & & Lifetime & $15,000 \mathrm{~h}$ \\
\hline & Replacement cost & $140 \$$ & \multirow{3}{*}{ Other inputs [23] } & $\begin{array}{l}\text { Lifetime of } \\
\text { project }\end{array}$ & 25 \\
\hline & O\&M cost & 10 \$/year & & Inflation rate & $2 \%$ \\
\hline & Lifetime & 8 years & & $\begin{array}{c}\text { Nominal } \\
\text { discount rate }(\%)\end{array}$ & $8 \%$ \\
\hline
\end{tabular}

3.5. Mathematical Model of Each Component

\subsubsection{Modelling of Solar PVS}

Photovoltaic system (PVS) output 'P PVs' is critical for modelling solar array into renewable energy generating systems, and it must be estimated.

The output power of solar PVS is evaluated using Equation (1) [57]:

$$
\mathrm{P}_{\mathrm{PVS}}=\left(\frac{\mathrm{S}}{\mathrm{S}_{\mathrm{S}}}\right) \mathrm{D}_{\mathrm{F}} \mathrm{P}_{\mathrm{R}}
$$

Based on temperature effect, the output power of solar PVS is evaluated using Equation (2) [42]:

$$
\mathrm{P}_{\mathrm{PVS}}=\left(\frac{\mathrm{S}}{\mathrm{S}_{\mathrm{s}}}\right) \mathrm{D}_{\mathrm{F}} \mathrm{P}_{\mathrm{R}}\left[\mathrm{S}_{\mathrm{C}}\left(\mathrm{T}_{\mathrm{PVC}}-\mathrm{T}_{\mathrm{SPVC}}\right)+1\right]
$$


where $S$ is the radiation from the sun that falls on the ground in $\mathrm{kW} / \mathrm{m}^{2}, \mathrm{~S}_{\mathrm{s}}$ is the standard radiation in $\mathrm{kW} / \mathrm{m}^{2}, \mathrm{D}_{\mathrm{F}}$ is known as derating factor, $\mathrm{P}_{\mathrm{R}}$ is the rated PVS capacity in $\mathrm{kW}, \mathrm{S}_{\mathrm{C}}$ is termed as a coefficient of solar power in $\% /{ }^{\circ} \mathrm{C}, \mathrm{T}_{\mathrm{PVC}}$ is the PVS temperature of cell in ${ }^{\circ} \mathrm{C}$ and $\mathrm{T}_{\mathrm{SPVC}}$ is the standard photovoltaic cell temperature. The derating of solar is $80 \%$ and standard radiation ' $\mathrm{S}$ ' is $1 \mathrm{~kW} / \mathrm{m}^{2}$. The temperature effect on power is $-0.500 \% /{ }^{\circ} \mathrm{C}$, standard test condition efficiency is $13 \%$.

The photovoltaic cell temperature ' $\mathrm{T}_{\mathrm{PVC}}$ ' is evaluated from Equation (3):

$$
\mathrm{T}_{\mathrm{PVC}}=\mathrm{S}\left(\frac{\mathrm{ta}}{\mathrm{H}_{\mathrm{c}}}\right)\left(1-\frac{\eta_{\mathrm{PVC}}}{\mathrm{ta}}\right)+\mathrm{T}_{\mathrm{a}}
$$

where ta is the transmittance absorbance, $\frac{\text { ta }}{\mathrm{H}_{\mathrm{C}}}$ is evaluated from the producer data, $\eta_{\mathrm{PVC}}$ is the photovoltaic cell efficiency in $\%$ and $\mathrm{T}_{\mathrm{a}}$ is the temperature on atmosphere in ${ }^{\circ} \mathrm{C}$.

The ratio $\frac{\text { ta }}{\mathrm{H}_{\mathrm{c}}}$ is assumed to be constant, and it can be evaluated using Equation (4):

$$
\frac{\mathrm{ta}}{\mathrm{H}_{\mathrm{C}}}=\frac{\mathrm{T}_{\mathrm{NC}}-\mathrm{T}_{\mathrm{aNC}}}{\mathrm{s}_{\mathrm{NCT}}}
$$

where $\mathrm{T}_{\mathrm{NC}}$ is the nominal cell temperature in ${ }^{\circ} \mathrm{C}, \mathrm{T}_{\mathrm{aNC}}$ is the ambient temperature with nominal temperature of cell in ${ }^{\circ} \mathrm{C}$, and $\mathrm{s}_{\mathrm{NCT}}$ is the solar radiation with nominal temperature of the cell in $\mathrm{kW} / \mathrm{m}^{2}$.

To evaluate the photovoltaic cell temperature ' $\mathrm{T}_{\mathrm{PVC}}$ ' with the ratio $\frac{\mathrm{ta}}{\mathrm{H}_{\mathrm{c}}}$, then substitute Equation (4) in Equation (3):

$$
\mathrm{T}_{\mathrm{PVC}}=\mathrm{S}\left(\frac{\mathrm{T}_{\mathrm{NC}}-\mathrm{T}_{\mathrm{aNC}}}{\mathrm{s}_{\mathrm{NCT}}}\right)\left(1-\frac{\eta_{\mathrm{PVC}}}{\mathrm{ta}}\right)+\mathrm{T}_{\mathrm{a}}
$$

The efficiency of the photovoltaic cell depends on photovoltaic cell temperature. Equation (6) below is the modified equation from Equation (5) by considering the efficiency of maximum power under operating standard conditions:

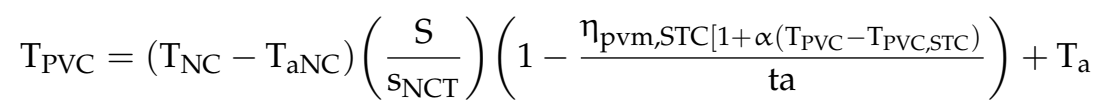

where $\alpha$ is the temperature power coefficient.

In most cases, the value of $\alpha$ is negative, which implies the photovoltaic cell efficiency ' $\eta_{\mathrm{PVC}}$ ', is inversely proportional to the photovoltaic cell temperature ' $\mathrm{T}_{\mathrm{PVC}}$ '. Then, the photovoltaic cell temperature ' $\mathrm{T}_{\mathrm{PVC}}$ ' represents on the basis of Equation (7):

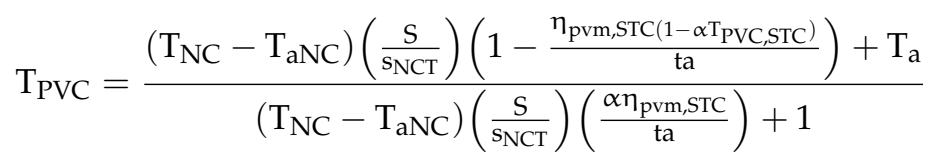

\subsubsection{Modelling of Wind Turbine System}

Wind turbines (WT) are erected to catch the kinetic energy of air flow and then use a rotor with $\mathrm{n}$ number of blades attached to a generator to convert mechanical energy supplied in wind into electrical energy. Since the speed of winds change with height, estimating wind speed at the height of the hub is critical. The hub height wind speed of wind turbine ' $W_{\text {hub }}$ ' is estimated using the following Equation (8) [66]:

$$
\mathrm{W}_{\text {hub }}=\frac{\ln \left(\mathrm{WT}_{\mathrm{hub}} / \mathrm{L}_{\mathrm{S}}\right)}{\ln \left(\mathrm{WT}_{\mathrm{ane}} / \mathrm{L}_{\mathrm{S}}\right)} \cdot \mathrm{W}_{\mathrm{ane}}
$$

where $\mathrm{WT}_{\text {hub }}$ is the WT hub height in meters, $\mathrm{WT}_{\text {ane }}$ is the anemometer height in meters, $\mathrm{L}_{\mathrm{S}}$ is the roughness surface length, and $\mathrm{W}_{\text {ane }}$ is the speed of wind at the anemometer height in $\mathrm{m} / \mathrm{s}$. 
The area swept is the area which the rotation of wind turbine blades covers. The wind speed ' $w$ ' is also an important parameter in estimating the power output of the WT. The cut-in speed of wind, rated speed of wind and cut-out speed of wind are $4 \mathrm{~m} / \mathrm{s}, 14 \mathrm{~m} / \mathrm{s}$, and $24 \mathrm{~m} / \mathrm{s}$, respectively. The power output of wind turbine (WT) ' $\mathrm{P}_{\mathrm{WT}}$ ' is evaluated based on Equation (9) [42]:

$$
\mathrm{P}_{\mathrm{WT}}=\left(\frac{\mathrm{w}^{3} \rho_{\mathrm{a}} \mathrm{A}_{\mathrm{c}} \mathrm{C}_{\mathrm{w}}}{2}\right) * 10^{-3}
$$

where $\mathrm{w}$ is the speed of wind in $\mathrm{m} / \mathrm{s}, \rho_{\mathrm{a}}$ is the density of air $\left(0.01225 * 10^{-2} \mathrm{~kg} / \mathrm{m}^{3}\right), \mathrm{A}_{C}$ is the area swept of WT in $\mathrm{m}^{2}$ and $\mathrm{C}_{\mathrm{W}}$ is the wind turbine power coefficient.

\subsubsection{Modelling of Battery}

The required number of batteries is evaluated from Equation (10) [52]:

$$
\mathrm{N}_{\mathrm{bat}}=\frac{\mathrm{n}_{\mathrm{ad}} * \mathrm{P}_{\mathrm{d}}}{\mathrm{C}_{\mathrm{nb}} * \eta_{\mathrm{b}} * \mathrm{DOD}}
$$

where $\mathrm{n}_{\mathrm{ad}}$ is the autonomy days by battery, $\mathrm{P}_{\mathrm{d}}$ is the daily average consumption of power in $\mathrm{kW}, \mathrm{C}_{\mathrm{nb}}$ is the battery nominal capacity, $\eta_{\mathrm{b}}$ is the battery roundtrip efficiency in $\%$ and DOD is the depth of discharge.

The product of nominal voltage and storage element in each string is known as bus voltage. The storage element in series is termed as string. The total string count is evaluated based on suitable battery count, battery voltage rating and DC bus voltage. The total string count is inversely proportional to the DC bus voltage. Then, this total string count ' $\mathrm{N}_{\mathrm{str}}$ ' is determined by Equation (11):

$$
\mathrm{N}_{\mathrm{str}}=\frac{\mathrm{N}_{\mathrm{bat}} * \mathrm{~V}_{\mathrm{bat}}}{\mathrm{V}_{\mathrm{DCV}}}
$$

where $\mathrm{V}_{\text {bat }}$ is the battery voltage rating and $\mathrm{V}_{\mathrm{DCV}}$ is the voltage on DC bus.

The battery state of charge (SOC) under charging condition is evaluated by Equation (12):

$$
\operatorname{SOC}(t)=\operatorname{SOC}(t-1)+\left(\left(P_{P V S}(t)+P_{W T}(t)\right)-\left(E_{\text {res }}(t)+E_{\mathrm{el} 2}(t)\right) d t \eta_{c b} / C_{b}\right.
$$

where SOC $(t-1)$ is the battery SOC in a previous time period, $P_{P V S}(t)$ is the power output of PVS for a time ' $t$ ', $P_{W T}$ is the power output of $W T, E_{\text {res }}(t)$ is the residential load for time ' $t$ ' in a year, $E_{\mathrm{el} 2}(t)$ is the commercial and street light load for time ' $t$ ' in a year, and $C_{b}$ is the battery capacity.

The battery charging and discharging efficiency $\eta_{\mathrm{cb}}$ and $\eta_{\mathrm{db}}$, respectively, are evaluated based on the square root of round trip efficiency.

The battery state of charge (SOC) under a discharging condition is evaluated by Equation (13):

$$
\operatorname{SOC}(t)=\operatorname{SOC}(t-1)-\left(\left(E_{\text {res }}(t)+E_{\mathrm{el} 2}(t)\right)-\left(P_{\mathrm{PVS}}(t)+P_{\mathrm{WT}}(\mathrm{t})\right) d t / \eta_{\mathrm{db}} C_{b}\right.
$$

The constraints considered during the optimization process to obtain the result with a certain limit. For SOC, the constraints followed are given in Equation (14):

$$
\mathrm{SOC}_{\min }<\mathrm{SOC}(\mathrm{t})<\mathrm{SOC}_{\max }
$$

where $\mathrm{SOC}_{\min }$ is a minimum state of charge and $\mathrm{SOC}_{\max }$ is a maximum state of charge.

\subsubsection{Modelling of Converter}

The hybrid non-conventional source generates output voltage in either DC or AC. Thus, to satisfy the power supply of load requirement, the converter is essential for converting either DC input to AC output or AC input to DC output. The converter will either act as an inverter or a rectifier based on the requirement. In this analysis, the efficiency of converter is kept constant in HOMER for converter operation in the system. Thus, the output of the converter is based on its input and efficiency (96\%). 
The load side power given from converter output is given in Equation (15) [65]:

$$
\mathrm{P}_{1 \mathrm{~s}}(\mathrm{t})=\mathrm{P}_{\text {input }}(\mathrm{t}) * \eta_{\text {conv }}
$$

where $P_{\text {input }}(t)$ is the converter input power, and $\eta_{\text {conv }}$ represents the converter efficiency.

\subsubsection{Modelling of Generator}

The fuel is essential for operating a diesel generator. The consumption of fuel on an hourly basis is taken for consideration to operate a diesel generator in HOMER. The rate of fuel consumption in a diesel generator is evaluated using Equation (16) [52]:

$$
\mathrm{F}_{\mathrm{DG}}(\mathrm{t})=\mathrm{F}_{\mathrm{C}} * \mathrm{P}_{\mathrm{RDG}}+\mathrm{F}_{\mathrm{S}} * \mathrm{P}_{\mathrm{ODG}}(\mathrm{t})
$$

where $F_{C}$ is the intercept coefficient, $F_{S}$ is the fuel curve slope, $P_{R D G}$ is the rated power output of DG and $P_{O D G}(t)$ is the real power output of DG. $F_{C}$ and $F_{S}$ are represented as constants.

\subsection{Economic and Reliability Features}

The net present cost $\left(\mathrm{C}_{\mathrm{NP}}\right)$ is one of the main parameters in a system optimization process using HOMER. The feasible result of optimization process will be decided based on $C_{N P}$ and levelized energy cost (LEC). The $C_{N P}$ depends on annualized cost and capital recovery factor. The net present $\operatorname{cost}{ }^{\prime} \mathrm{C}_{\mathrm{NP}}$ ' is represented by Equation (17) [65]:

$$
\mathrm{C}_{\mathrm{NP}}=\mathrm{C}_{\mathrm{annual}, \mathrm{T}}\left(\frac{1}{\mathrm{RF}_{\mathrm{C}}\left(\mathrm{r}_{\mathrm{i}}, \mathrm{l}\right)}\right)
$$

where $C_{N P}$ is the net present cost in $\$, C_{a n n u a l, T}$ is the annualized total cost in $\$, R F_{C}$ is the capital recovery factor, $r_{i}$ is based on inflation discount rate in $\%$, and $l$ is the project lifetime.

The capital recovery factor $\mathrm{RF}_{\mathrm{C}}\left(\mathrm{r}_{1}, 1\right)$ is evaluated based on Equation (18):

$$
\operatorname{RF}_{\mathrm{c}}\left(\mathrm{r}_{\mathrm{i}}, 1\right)=\left(\frac{\mathrm{r}_{\mathrm{i}}\left(\mathrm{r}_{\mathrm{i}}+1\right)^{1}}{\left(\mathrm{r}_{\mathrm{i}}+1\right)^{1}-1}\right)
$$

where

$$
r_{i}=\frac{r_{d}-i_{f}}{r_{d}+i_{f}}
$$

where $r_{i}$ is the interest rate annually, $r_{d}$ is the discount rate in $\%$ and $i_{f}$ is the inflation rate in $\%$.

The total annualized cost ' $\mathrm{C}_{\mathrm{annual}, \mathrm{T}}$ ' is the sum of capital cost ' $\mathrm{C}_{\mathrm{ca}}$ ', replacement cost ' $\mathrm{C}_{\text {rep }}$ ' and operation and maintenance cost ' $\mathrm{C}_{\mathrm{mo}}$ ' of all components in the hybrid system in $\$$. This cost is evaluated from Equation (20):

$$
\mathrm{C}_{\text {annual, } \mathrm{T}}=\mathrm{C}_{\mathrm{ca}}+\mathrm{C}_{\mathrm{rep}}+\mathrm{C}_{\mathrm{mo}}
$$

The capital cost is the sum of capital cost of photovoltaic system ' $\mathrm{C}_{\mathrm{cpvs}}$ ', wind turbine ' $\mathrm{C}_{\mathrm{cwt}}$ ', battery ' $\mathrm{C}_{\mathrm{cbat}}$ ', converter ' $\mathrm{C}_{\mathrm{ccon}}$ ' and diesel generator ' $\mathrm{C}_{\mathrm{cdg}}$ '. This cost is evaluated from Equation (21):

$$
\mathrm{C}_{\mathrm{ca}}=\mathrm{C}_{\mathrm{cpvs}}+\mathrm{C}_{\mathrm{cwt}}+\mathrm{C}_{\mathrm{cbat}}+\mathrm{C}_{\mathrm{ccon}}+\mathrm{C}_{\mathrm{cdg}}
$$

The replacement cost is the sum of the replacement cost of photovoltaic system ' $\mathrm{C}_{\mathrm{rpvs}}$ ', wind turbine ' $\mathrm{C}_{\mathrm{rwt}}$ ', battery ' $\mathrm{C}_{\mathrm{rbat}}$ ', converter ' $\mathrm{C}_{\mathrm{rcon}}$ ' and diesel generator ' $\mathrm{C}_{\mathrm{rdg}}$ '. This cost is evaluated from Equation (22):

$$
\mathrm{C}_{\text {rep }}=\mathrm{C}_{\mathrm{rpvs}}+\mathrm{C}_{\mathrm{rwt}}+\mathrm{C}_{\mathrm{rbat}}+\mathrm{C}_{\mathrm{rcon}}+\mathrm{C}_{\mathrm{rdg}}
$$


The operation and maintenance cost is the sum of operation and maintenance cost of photovoltaic system ' $C_{\text {mopvs', wind turbine ' }} \mathrm{C}_{\text {mowt }}$ ', battery ' $\mathrm{C}_{\text {mobat }}$, , converter ' $\mathrm{C}_{\text {mocon }}$ ' and diesel generator ' $C_{\text {modg }}$. This cost is evaluated from Equation (23):

$$
\mathrm{C}_{\text {mo }}=\mathrm{C}_{\text {mopvs }}+\mathrm{C}_{\text {mowt }}+\mathrm{C}_{\text {mobat }}+\mathrm{C}_{\text {mocon }}+\mathrm{C}_{\text {modg }}
$$

The levelized Energy cost (LEC) is the total annualized cost ' $C_{\mathrm{annual}, \mathrm{T}}$ ' to the sum of residential $E_{\text {res }}(t)$ and electric load-2 $E_{\text {el2 }}(t)$. The LEC is calculated from Equation (24) [65]:

$$
\mathrm{LEC}=\frac{\mathrm{C}_{\mathrm{annual}, \mathrm{T}}}{\sum_{\mathrm{t}=1}^{8760} \mathrm{E}_{\mathrm{res}}(\mathrm{t})+\mathrm{E}_{\mathrm{el} 2}(\mathrm{t})}
$$

In this study, two reliability indices are evaluated in HOMER software. The expected energy not served (ENS) and Loss of generation probability (LGP) are evaluated during the optimization process.

The Energy not served (ENS) is the reliability index used to evaluate the expected generation $\mathrm{E}_{\mathrm{G}}(\mathrm{t})$, which is not generated to satisfy load demand for each time period ' $t$ '. This index is represented in $\mathrm{kWh} / \mathrm{yr}$, and it is represented by Equation (25)

$$
\mathrm{ENS}=\sum_{\mathrm{t}=1}^{8760} \mathrm{E}_{\mathrm{d}}(\mathrm{t})
$$

where

$$
\mathrm{E}_{\mathrm{d}}(\mathrm{t})=\left(\mathrm{E}_{\mathrm{res}}(\mathrm{t})+\mathrm{E}_{\mathrm{el} 2}(\mathrm{t})\right)-\left(\mathrm{P}_{\mathrm{PVS}}(\mathrm{t})+\mathrm{P}_{\mathrm{WT}}(\mathrm{t})+\mathrm{P}_{\mathrm{DG}}(\mathrm{t})\right)
$$

The loss of generation probability (LGP) is the ratio of expected energy not served (ENS) to the total load demand $\mathrm{E}_{\mathrm{res}}(\mathrm{t})$ and $\mathrm{E}_{\mathrm{el} 2}(\mathrm{t})$. This index is represented in $\%$, and it is represented by Equation (27):

$$
\text { LGP }=\frac{\sum_{t=1}^{8760} E_{d}(t)}{\sum_{t=1}^{8760} E_{\text {res }}(t)+E_{e l 2}(t)}
$$

\subsection{Electrical Features}

The electrical parameters like capacity factor, PVS penetration and renewable fraction are evaluated during the process of optimization.

Capacity factor ' $\mathrm{CF}^{\prime}$ ' is defined as the ratio of mean power output of PVS/WT/DG to the total capacity of PVS/WT/DG as represented in Equation (28):

$$
\mathrm{CF}=\frac{\text { Mean output power of PVS/ WT / DG }(\mathrm{kW})}{\text { Total capacity of PVS/ WT/ DG }(\mathrm{kW})}
$$

PVS penetration is the ratio of mean power output of the photovoltaic system (PVS) to the average load demand. Mathematically, it is represented by the following Equation (29):

$$
\text { PVS penetration }=\frac{\text { Mean output power of PVS }\left(\frac{\mathrm{kWh}}{\text { day }}\right)}{\text { Average load demand }\left(\frac{\mathrm{kWh}}{\text { day }}\right)}
$$

Renewable fraction ' $R F^{\prime}$ ' is termed as the energy fraction in which the energy is delivered from a non-conventional source to load. Mathematically, it is represented by following Equation (30):

$$
\mathrm{RF}=1-\frac{\text { Total DG power generation }\left(\frac{\mathrm{kWh}}{\mathrm{yr}}\right)}{\text { Total load consumption }\left(\frac{\mathrm{kWh}}{\mathrm{yr}}\right)}
$$




\section{Optimization Results and Discussion}

\subsection{Analysis of Various Tracking Systems Used in Different Hybrid Configurations Based on Various Aspects}

Table 5 shows the levelized energy cost (LEC), net present cost $\left(C_{N P}\right)$, loss of generation probability (LGP), Expected energy not served (ENS) and emissions analysis for different configurations like PVS/DG, WT/DG, PVS/WT/DG and PVS/WT with fixed axis without tracking system (FSWT), tracking system on a horizonal axis (TSHA), tracking system on a vertical axis (TSVA) and tracking system on dual axis (TSDA). The results obtained from HOMER based on the input parameters are given in this Table 5. The LEC is low in PVS/DG and PVS/WT/DG configuration at $0.223 \$ / \mathrm{kWh}$ in FSWT. The net present cost is low in PVS/WT/DG. The LGP and ENS are nil in all configurations except PVS/WT. This is due to the random nature of renewable source since it depends on environmental effects. The advantage of PVS/WT configuration is to supply power without emissions, but the other three configurations produce emissions between $12,228.4 \mathrm{~kg} / \mathrm{yr}$ and $119,538.9 \mathrm{~kg} / \mathrm{yr}$. The cost of a tracking system on the horizontal axis, vertical axis and dual axis are $\$ 90$, $\$ 100$ and $\$ 180$, respectively, and are used for performing optimization results. While using TSHA in PVS/DG, PVS/WT/DG and PVS/WT, the LEC is less in PVS/DG and $\mathrm{PVS} / \mathrm{WT} / \mathrm{DG}$ at $0.224 \$ / \mathrm{kWh}$, but the total emission is more in these two configurations at $12,449 \mathrm{~kg} / \mathrm{yr}$. The total emission is the sum of $\mathrm{CO}_{2}$ emission and other emissions. The other emissions include carbon monoxide, sulphur dioxide, particulate matter, unburned hydrocarbons and nitrogen oxides which emit less from a diesel generator compared to $\mathrm{CO}_{2}$ content. The net present cost is increased by $49.42 \%$ in PVS/WT while comparing the result with PVS/DG and PVS/WT/DG. The LGP and ENS for PVS/WT are $0.0722 \%$ and $113 \mathrm{kWh} / \mathrm{yr}$.

Table 5. Cost, reliability and emission analysis for various configurations with different TS.

\begin{tabular}{|c|c|c|c|c|c|c|c|c|c|}
\hline TS & Parameters & PVS/DG & WT/DG & PVS/WT/DG & PVS/WT & TS & PVS/DG & PVS/WT/DG & PVS/WT \\
\hline \multirow{7}{*}{ FSWT } & LEC $(\$ / \mathrm{kWh})$ & 0.223 & 0.410 & 0.223 & 0.361 & \multirow{7}{*}{ TSVA } & 0.223 & 0.222 & 0.383 \\
\hline & $\mathrm{C}_{\mathrm{NP}}(\$)$ & 449,574 & 827,473 & 449,573 & 727,327 & & 448,532 & 448,269 & 771,189 \\
\hline & LGP (\%) & 0 & 0 & 0 & 0.0673 & & 0.0330 & 0.0323 & 0.0628 \\
\hline & ENS $(\mathrm{kWh} / \mathrm{yr})$ & 0 & 0 & 0 & 105 & & 51.5 & 50.3 & 97.9 \\
\hline & $\mathrm{CO}_{2}$ emission $(\mathrm{kg} / \mathrm{yr})$ & 12,048 & 117,775 & 12,148 & 0 & & 13,552 & 13,836 & 0 \\
\hline & $\begin{array}{c}\text { Other emission } \\
(\mathrm{kg} / \mathrm{yr})\end{array}$ & 180.47 & 1763.9 & 182 & 0 & & 203 & 207 & 0 \\
\hline & $\begin{array}{c}\text { Total emission } \\
(\mathrm{kg} / \mathrm{yr})\end{array}$ & $12,228.4$ & 119,538 & 12,330 & 0 & & 13,755 & 14,043 & 0 \\
\hline \multirow{7}{*}{ TSHA } & LEC (\$/kWh) & 0.224 & - & 0.224 & 0.336 & \multirow{7}{*}{ TSDA } & 0.226 & 0.226 & 0.400 \\
\hline & $\mathrm{C}_{\mathrm{NP}}(\$)$ & 452,516 & - & 452,516 & 676,153 & & 455,751 & 455,327 & 806,655 \\
\hline & LGP $(\%)$ & 0 & - & 0 & 0.0722 & & 0 & 0.0168 & 0.0635 \\
\hline & ENS (kWh/yr) & 0 & - & 0 & 113 & & 0 & 26.1 & 99 \\
\hline & $\mathrm{CO}_{2}$ emission $(\mathrm{kg} / \mathrm{yr})$ & 12,449 & - & 12,449 & 0 & & 14,055 & 15,590 & 0 \\
\hline & $\begin{array}{c}\text { Other } \\
\text { emission }(\mathrm{kg} / \mathrm{yr})\end{array}$ & 186.5 & - & 186.5 & 0 & & 210.6 & 233.6 & 0 \\
\hline & $\begin{array}{c}\text { Total emission } \\
(\mathrm{kg} / \mathrm{yr})\end{array}$ & $12,635.5$ & - & $12,635.5$ & 0 & & $14,265.6$ & $15,823.6$ & 0 \\
\hline
\end{tabular}

The levelized energy cost and net present cost are low in PVS/DG and PVS/WT/DG using TSVA when compared with PVS/WT configuration. The LEC is low at $0.222 \$ / \mathrm{kWh}$ in PVS/WT/DG when compared with other configurations using TSVA. Compared with other configurations, the LGP and ENS are high in PVS/WT even when used with TSVA. However, only in PVS/WT is there no emission due to the absence of DG. The net present cost is low at $\$ 455,327$ in the PVS/WT/DG system using TSDA when compared with other models. The wind turbine system representing WT/DG is simulated with a fixed axis without a tracking system (FSWT) only since a solar source is necessary while analysing using solar trackers.

The above Figure 5 shows the levelized energy cost (LEC) and net present cost $\left(\mathrm{C}_{\mathrm{NP}}\right)$ in PVS/DG, WT/DG, PVS/WT/DG and PVS/WT. The optimization results given in Figure 5a show that the LEC is low in PVS/WT/DG configurations using TSVA at $0.222 \$ / \mathrm{kWh}$, which is $42 \%$ less than the system with PVS/WT and $0.44 \%$ less than the 
system with PVS/DG. For the system with other tracking systems and FSWT, the LEC is higher than $0.222 \$ / \mathrm{kWh}$. The optimization results given in Figure $5 \mathrm{~b}$ shows that the net present cost is higher in WT/DG and PVS/WT. In PVS/WT/DG with FSWT, the net present cost $\left(\mathrm{C}_{\mathrm{NP}}\right)$ is $45.66 \%$ lower when compared to the $\mathrm{C}_{\mathrm{NP}}$ of WT/DG. In the hybrid system consisting of PVS/DG or PVS/WT/DG using TSHA, the net present cost is $33.07 \%$ lower when compared to net present cost of PVS/WT. In the PVS/WT/DG configuration with TSVA, the net present cost is $41.87 \%$ lower when compared to net present cost of PVS/WT. Similarly, TSDA used in PVS/WT/DG configuration has a net present cost which is $43.55 \%$ lower when compared to the net present cost of PVS/WT.

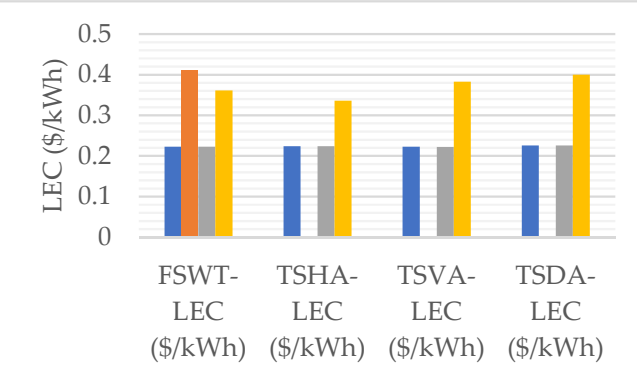

口VS/DG $\square \mathrm{WT} / \mathrm{DG} \backsim \mathrm{PVS} / \mathrm{WT} / \mathrm{DG} \backsim \mathrm{PVS} / \mathrm{WT}$

(a)

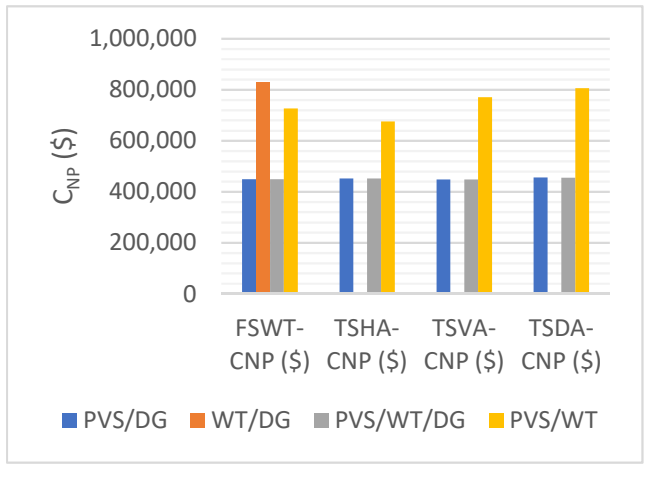

(b)

Figure 5. Cost for different tracking systems in various configurations (a) LEC ( $\$ / \mathrm{kWh})$; (b) net present cost ' $\mathrm{C}_{\mathrm{NP}}$ ' (\$).

The above Figure 6 shows the total emissions for various configurations with different tracking systems. The optimization results show that the emissions are significantly more in the system with WT/DG using FSWT at 119,538.9 kg/yr. In FSWT, the system consisting of PVS/DG has less emission of $12,228.4 \mathrm{~kg} / \mathrm{yr}$, which is $89.68 \%$ lower than WT/DG. However, for PVS/WT configuration, the emission is nil for the system with various tracking techniques. The system consisting of PVS/DG and PVS/WT/DG with TSHA produces the same emission of 12,449 kg/yr. The system consisting of PVS/DG and PVS/WT/DG with TSVA produces emission of 13,755 kg/yr and 14,043 kg/yr, respectively. The system consists of PVS/DG and PVS/WT/DG with TSDA produces emission of $14,265.6 \mathrm{~kg} / \mathrm{yr}$ and $15,823.6 \mathrm{~kg} / \mathrm{yr}$, respectively.

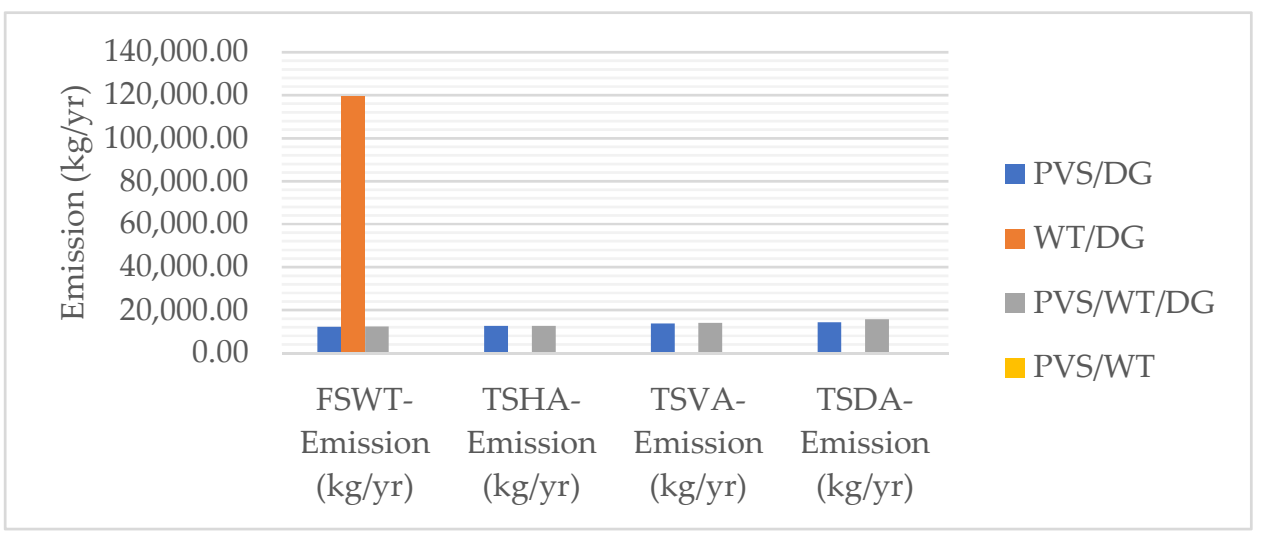

Figure 6. Total emission for different tracking systems in various configurations.

Table 6 shows the electrical parameters analyses for various configurations with different tracking systems. In a fixed system without tracking (FSWT), the PVS production and PVS penetration are high in PVS/WT configuration. Since the diesel generator is not included in this configuration, PVS capacity of $519 \mathrm{~kW}$ is used to meet the load demand. 
Similarly, the PVS production is high in PVS/WT configuration for TSHA, TSVA and TSDA as shown in Table 6. The $19 \mathrm{~kW}$ wind turbine capacity is used in WT/DG configuration along with the diesel generator of $85 \mathrm{~kW}$ capacity to meet the load demand. The usage of $82 \mathrm{kWh}$ capacity lithium-ion battery is less in WT/DG configuration only, while, in other configurations, solar plays an important role which increases the use of battery. The usage of diesel generator for electricity production is less $(5-6.96 \%)$ for various configurations using different tracking systems except WT/DG with FSWT. The optimization results obtained for production of different sources in $\mathrm{kWh} / \mathrm{yr}$ are shown in Table 6 . The capacity factors evaluated for each method are summarized in Table 6. Only in WT/DG configuration is the fuel consumption more at 44,993 L/yr since the production of DG for this case is $154,310 \mathrm{kWh} / \mathrm{yr}$. The usage of a converter in the different model is highlighted, which is used based on the power flow of $A C$ and DC bus. The renewable fraction for each case varies from $87-100 \%$ except WT/DG configuration. The PVS/WT has 100\% renewable fraction since the system uses only solar and wind systems.

In Figure 7, the comparison of different configurations for various tracking systems. PVS production growth in \% when compared to fixed system without tracking (FSWT) is shown. When compared with FSWT, 7.78\% power production is increased in PVS/DG, $7.30 \%$ is increased in PVS/WT/DG and 7.38\% is increased in PVS/WT while using a tracking system on a horizonal axis (TSHA). When compared to FSWT, 10.73\% power production is increased in PVS/DG, 9.77\% is increased in PVS/WT/DG and $10.35 \%$ is increased in PVS/WT while using a tracking system on a vertical axis (TSVA). Finally, when compared to FSWT, 33.40\% power production is increased in PVS/DG, 32.91\% is increased in PVS/WT/DG and 32.78\% is increased in PVS/WT while using a tracking system on a dual axis (TSDA).

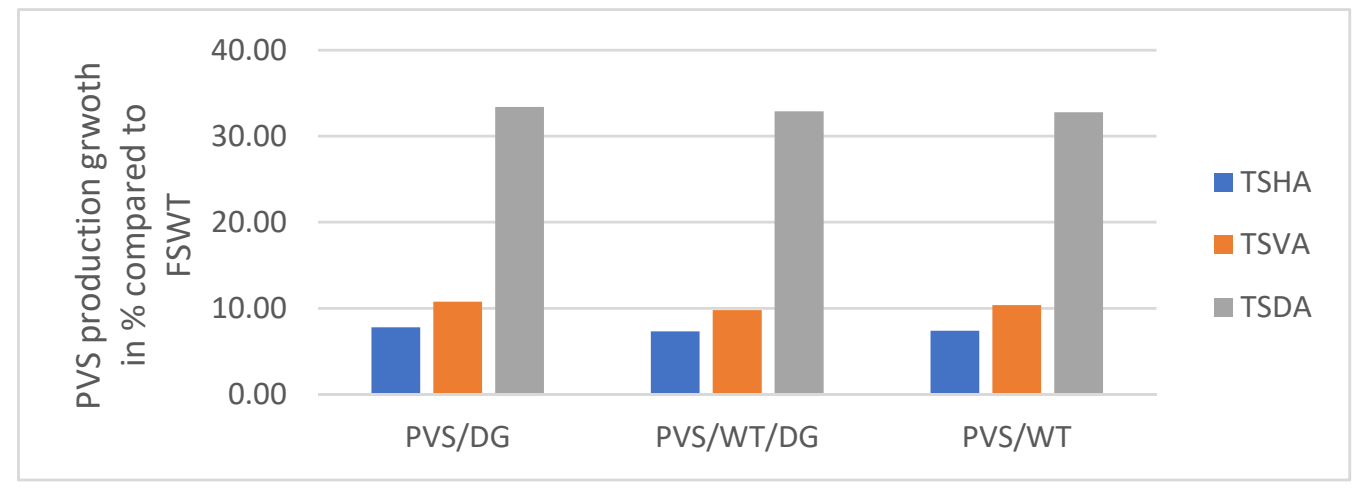

Figure 7. Comparison of different configurations for various tracking systems-PVS production growth in \% when compared to FSWT.

\subsection{Analysis of Best System Based on Solar Tracking Technique-Optimization Results}

From the previous section, using HOMER software, the system with solar and diesel generators consisting of a tracking system on a vertical axis (TSVA) is suitable for Kalpeni Island with low levelized energy cost (LEC) at $0.222 \$ / \mathrm{kWh}$ and net present cost $\left(\mathrm{C}_{\mathrm{NP}}\right)$ at $\$ 448,269.5$. The tracking system on a vertical axis (TSVA) increases solar power production between $9.77 \%$ and $10.73 \%$ while comparing solar power production from FSWT. Based on LEC cost, TSVA is preferred even though the solar production of power using TSDA is greater. The best optimization results of solar, wind and diesel generator reveal that only the solar and diesel generators are operated during the optimization process with less levelized energy cost as shown in Figure 8. 
Table 6. Electrical parameters' analyses for various configurations with different TS.

\begin{tabular}{|c|c|c|c|c|c|c|c|c|c|c|}
\hline TS & Components & Parameters & PVS/DG & WT/DG & PVS/WT/DG & PVS/WT & TS & PVS/DG & PVS/WT/DG & PVS/WT \\
\hline \multirow{8}{*}{ FSWT } & \multirow{3}{*}{ PVS } & Capacity $(\mathrm{kW})$ & 146 & - & 146 & 519 & \multirow{8}{*}{ TSVA } & 135 & 136 & 495 \\
\hline & & $\begin{array}{c}\text { Production } \\
\text { (kWh/yr) }\end{array}$ & 245,487 & - & 246,575 & 874,855 & & 251,356 & 252,135 & 920,740 \\
\hline & & $\begin{array}{l}\text { Capacity factor (\%) } \\
\text { PVS penetration }(\%)\end{array}$ & $\begin{array}{l}19.3 \\
157\end{array}$ & $\begin{array}{l}- \\
-\end{array}$ & $\begin{array}{l}19.3 \\
158\end{array}$ & $\begin{array}{l}19.3 \\
561\end{array}$ & & $\begin{array}{l}21.2 \\
161\end{array}$ & $\begin{array}{l}21.2 \\
162\end{array}$ & $\begin{array}{l}21.2 \\
590\end{array}$ \\
\hline & & Capacity $(\mathrm{kW})$ & - & 19 & - & - & & - & - & - \\
\hline & WT & $\begin{array}{l}\text { Production } \\
\text { (kWh/yr) }\end{array}$ & - & 17,939 & - & - & & - & - & - \\
\hline & & Capacity factor (\%) & - & 10.8 & - & - & & - & - & - \\
\hline & \multirow{2}{*}{ LI battery } & $\begin{array}{c}\text { Nominal Capacity } \\
(\mathrm{kWh})\end{array}$ & 527 & 82 & 526 & 703 & & 517 & 512 & 687 \\
\hline & & $\begin{array}{l}\text { Energy out } \\
\text { (kWh/yr) }\end{array}$ & 99,278 & 79,458 & 99,080 & 100,714 & & 97,468 & 97,690 & 98,182 \\
\hline \multirow{7}{*}{ FSWT } & \multirow{3}{*}{ DG } & Capacity (kW) & 85 & 85 & 85 & - & \multirow{7}{*}{ TSVA } & 85 & 85 & - \\
\hline & & $\begin{array}{c}\text { Production } \\
(\mathrm{kWh} / \mathrm{yr})\end{array}$ & 13,039 & 154,310 & 13,103 & - & & 17,636 & 18,058 & - \\
\hline & & $\begin{array}{l}\text { Fuel consumption } \\
(\mathrm{L} / \mathrm{yr})\end{array}$ & 4603 & 44993 & 4641 & - & & 5177 & 5286 & - \\
\hline & \multirow{3}{*}{ Converter } & Capacity (kW) & 70.3 & 52.2 & 68.3 & 81.9 & & 60.7 & 60.8 & 129 \\
\hline & & $\begin{array}{c}\text { Energy output } \\
\text { (kWh/yr) }\end{array}$ & 143,978 & 76,280 & 143,884 & 155,861 & & 146,110 & 146,206 & 155,868 \\
\hline & & Capacity factor (\%) & 23.4 & 16.7 & 24.1 & 21.7 & & 27.5 & 27.5 & 13.8 \\
\hline & \multicolumn{2}{|c|}{ Renewable fraction $(\%)$} & 91.6 & 1.06 & 91.6 & 100 & & 88.7 & 88.4 & 100 \\
\hline \multirow{15}{*}{ TSHA } & \multirow{3}{*}{ PVS } & Capacity $(\mathrm{kW})$ & 135 & - & 135 & 243 & \multirow{15}{*}{ TSDA } & 115 & 121 & 419 \\
\hline & & $\begin{array}{l}\text { Production } \\
\text { (kWh/yr) }\end{array}$ & 244,647 & - & 244,647 & 439,843 & & 257,949 & 271,603 & 937,777 \\
\hline & & $\begin{array}{l}\text { Capacity factor }(\%) \\
\text { PVS penetration }(\%)\end{array}$ & $\begin{array}{l}20.7 \\
157\end{array}$ & $\begin{array}{l}- \\
-\end{array}$ & $\begin{array}{l}20.7 \\
157\end{array}$ & $\begin{array}{l}20.7 \\
282\end{array}$ & & $\begin{array}{l}25.5 \\
165\end{array}$ & 174 & $\begin{array}{l}25.5 \\
601\end{array}$ \\
\hline & \multirow{3}{*}{ WT capacity } & Capacity (kW) & - & - & - & 38 & & - & - & - \\
\hline & & $\begin{array}{l}\text { Production } \\
\text { (kWh/yr) }\end{array}$ & - & - & - & 35,877 & & - & - & - \\
\hline & & Capacity factor $(\%)$ & - & - & - & 10.8 & & - & - & - \\
\hline & & $\begin{array}{c}\text { Nominal Capacity } \\
(\mathrm{kWh})\end{array}$ & 519 & - & 519 & 716 & & 519 & 510 & 894 \\
\hline & LI battery & $\begin{array}{c}\text { Energy out } \\
(\mathrm{kWh} / \mathrm{yr})\end{array}$ & 96,054 & - & 96,054 & 91,090 & & 93,231 & 95,881 & 99,047 \\
\hline & \multirow{3}{*}{ DG } & Capacity (kW) & 85 & - & 85 & - & & 85 & 85 & - \\
\hline & & $\begin{array}{l}\text { Production } \\
\text { (kWh/yr) }\end{array}$ & 13,472 & - & 13,472 & - & & 15,317 & 20,328 & - \\
\hline & & $\begin{array}{l}\text { Fuel consumption } \\
(\mathrm{L} / \mathrm{yr})\end{array}$ & 4756 & - & 4756 & - & & 5369 & 5956 & - \\
\hline & \multirow{3}{*}{ Converter } & Capacity $(\mathrm{kW})$ & 69.7 & - & 69.7 & 87.4 & & 70.6 & 63 & 82.3 \\
\hline & & $\begin{array}{l}\text { Energy output } \\
\text { (kWh/yr) }\end{array}$ & 143,633 & - & 143,633 & 130,279 & & 142,119 & 145,778 & 155,867 \\
\hline & & Capacity factor & 23.5 & - & 23.5 & 17.0 & & 23 & 26.4 & 21.6 \\
\hline & \multicolumn{2}{|c|}{ Renewable fraction (\%) } & 91.4 & - & 91.4 & 100 & & 90.2 & 87 & 100 \\
\hline
\end{tabular}

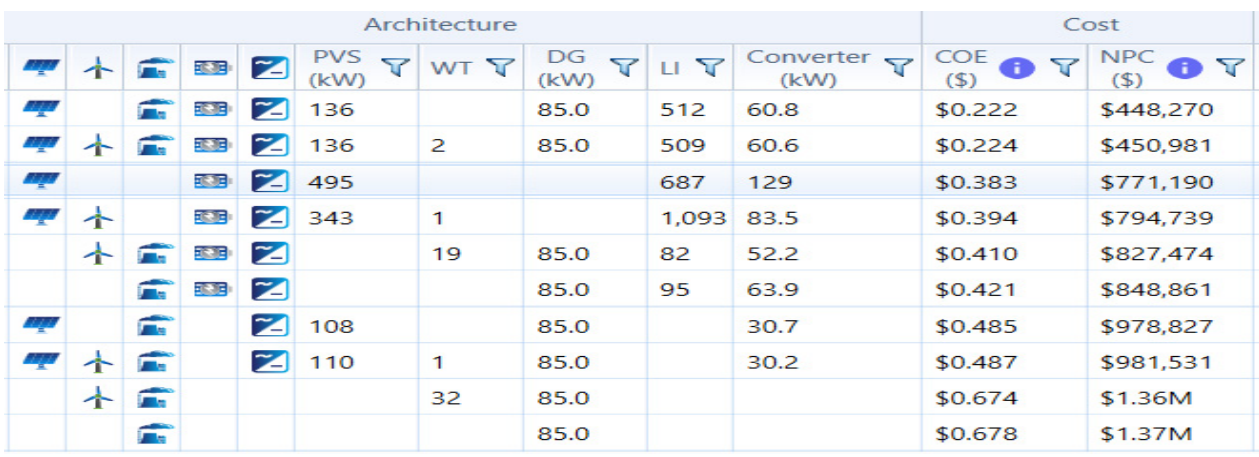

Figure 8. Optimization results from HOMER for solar, wind and generator with TSVA. 


\subsection{Benefits of Solar DG Source with TSVA on Kalpeni Island}

The simulation results of PVS/WT/DG configuration using HOMER shows that only PVS DG is operated with less levelized energy cost (LEC).

The comparison of a tracking system on vertical axis (TSVA) in various configurations is shown in Figure 9. The result on the tracking system on vertical axis for PVS DG WT configuration shows that only PVS DG are operating and show a better result when compared to other configurations. The levelized energy cost (LEC), net present cost $\left(C_{N P}\right)$ and loss of generation probability (LGP) are less in PVS/WT/DG configuration when compared to other results. The levelized energy cost (LEC), net present cost $\left(\mathrm{C}_{\mathrm{NP}}\right)$ and loss of generation probability (LGP) are $0.222 \$ / \mathrm{kWh}, \$ 448,269$ and $0.0323 \%$, respectively, which are less when compared to other configurations as shown in Figure 9. Thus, solar and DG using TSVA are suitable sources to use on Kalpeni Island. Thus, based on the benefits of the system considered, various analyses are performed in the following sections.

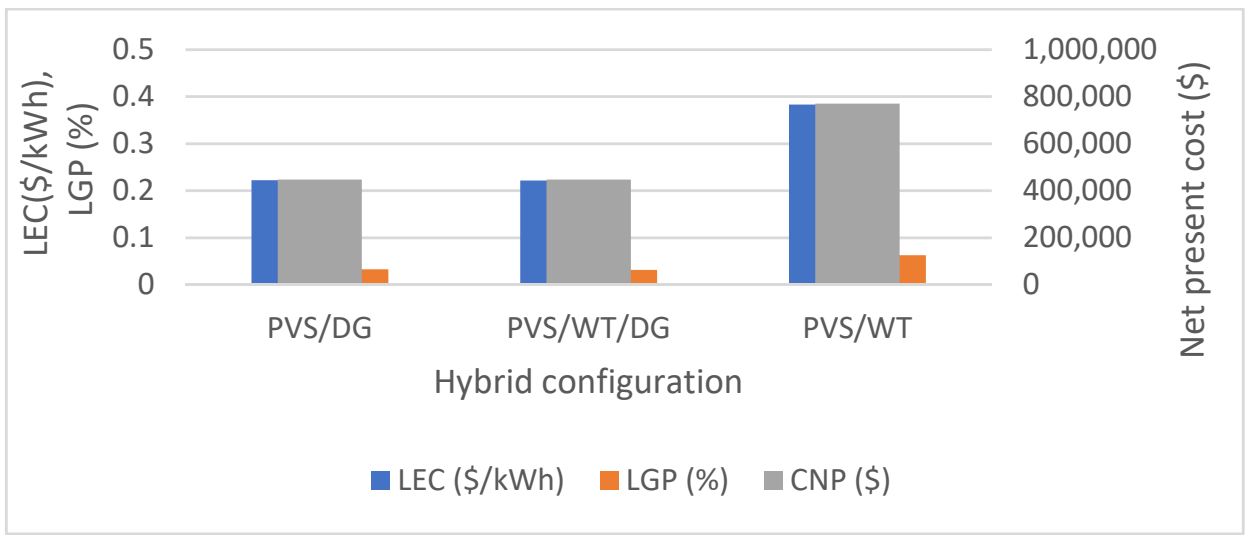

Figure 9. Comparison of TSVA in various hybrid configurations.

\subsection{Reliability Assessment for Solar DG Source Configuration with TSVA}

In Figure 10, the reliability indices for tracking system on a vertical axis (TSVA) are used in various configurations. The optimization results show that the expected energy not served (ENS) for PVS/DG, PVS/WT/DG and PVS/WT are $51.5 \mathrm{kWh} / \mathrm{yr}, 50.3 \mathrm{kWh} / \mathrm{yr}$ and $97.9 \mathrm{kWh} / \mathrm{yr}$, respectively. Similarly, the loss of generation probabilities (LGP) for the above configurations are $0.033 \%, 0.0323 \%$ and $0.0628 \%$, respectively. The result shows that ENS using PVS/WT is $90.09 \%$ more when compared to PVS/DG and $94.63 \%$ more when compared to PVS/WT/DG. Summarizing the above results, the PVS/WT/DG has lesser expected energy not served and loss of generation probability.

\subsection{Cost Assessment for Solar DG Source Configuration with TSVA}

The net present costs ' $\mathrm{C}_{\mathrm{NP}}$ ' for different components in solar DG configuration with TSVA technique are shown in Figure 11. The total net present capital cost is $\$ 208,988$, net present operating cost is $\$ 89,659$, net present replacement cost is $\$ 100,012$, net present salvage is $-\$ 18,721$ and net present resource is $\$ 68,332$. Thus, the total net present cost ' $\mathrm{C}_{\mathrm{NP}}$ ' is $\$ 448,269$. From Figure 11, it is noted that the capital cost for solar PVS is $\$ 100,379.78$, which is high compared to other components. The replacement cost for $1 \mathrm{kWh}$ lithium-Ion battery is $\$ 92,278.23$, which is high compared to other components since the lifetime of battery is only eight years. The operating cost for $1 \mathrm{kWh}$ lithium-Ion battery is high at $\$ 66,188.88$ compared to other components. 


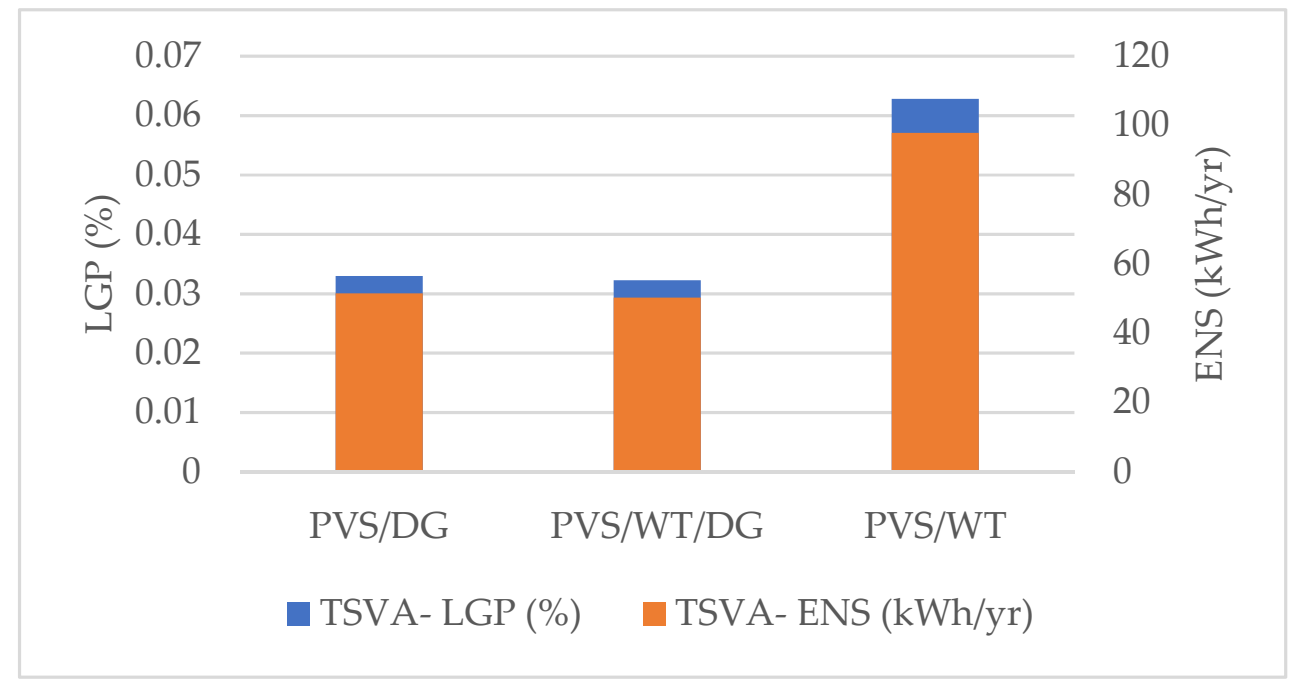

Figure 10. Reliability indices for TSVA used in various configurations.

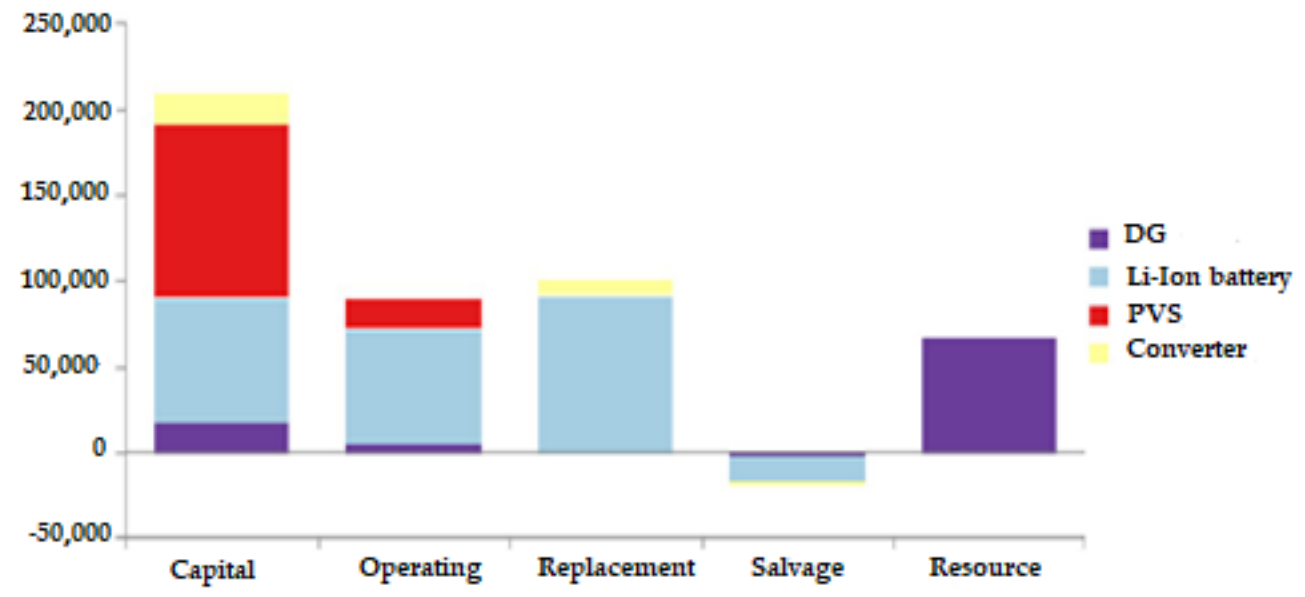

Figure 11. Cost assessment of different components in solar DG configuration with TSVA.

\subsection{Energy Balance of Solar DG with TSVA}

In Figure 12, the daily time-stamped analysis for the month of October using solar DG source with TSVA tracking technique is shown. The hourly data for PVS output power, load demand, autosize DG power output, $1 \mathrm{kWh}$ Li-Ion charge power and $1 \mathrm{kWh}$ Li-Ion discharge power are recorded on 12 October. The month of October is winter for the Kalpeni Island and as such the 25 households had not used air conditioners much. In addition, many households use water geysers. They use water geyser between 6.00 a.m. and $8.00 \mathrm{a} . \mathrm{m}$. and consequently the load demand increased from $13.29 \mathrm{~kW}$ to $44.29 \mathrm{~kW}$ as shown in Figure 12. The LED Street lights and grocery shop refrigerators are switched ON between 12.00 a.m. and 6.00 p.m. From 12.00 a.m. to 6.00 a.m., the solar PVS does not generate output due to insufficient solar radiation, but, at 7.00 a.m., it starts generating output to satisfy the load demand. The Li-Ion battery discharges power between 12.00 a.m. and $7.00 \mathrm{a} . \mathrm{m}$. to satisfy residential and electric load-2 demand. The discharging power is overlapping with the load demand from 12.00 a.m. to 7.00 a.m. and from 7.00 p.m. to 11.00 p.m. At 8.00 a.m., the diesel generator generated $44.49 \mathrm{~kW}$ to satisfy load demand of $44.49 \mathrm{~kW}$ and solar PVS generated $11.57 \mathrm{~kW}$, which is used to charge the battery. Between 8.00 a.m. and 6.00 p.m., the Li-Ion battery gets charged based on the output of solar PVS. On 12 October, solar PVS generated peak power of $97.30 \mathrm{~kW}$ at 1.00 p.m. Since sufficient solar radiation is available to generate power using solar PVS between 9.00 a.m. and 6.00 p.m., the diesel generator is not operated to avoid emission. After 6.00 p.m., there is 
no solar PVS output due to insufficient solar radiation. Thus, from 6.00 p.m. to 11.00 p.m., the Li-Ion battery discharges power.

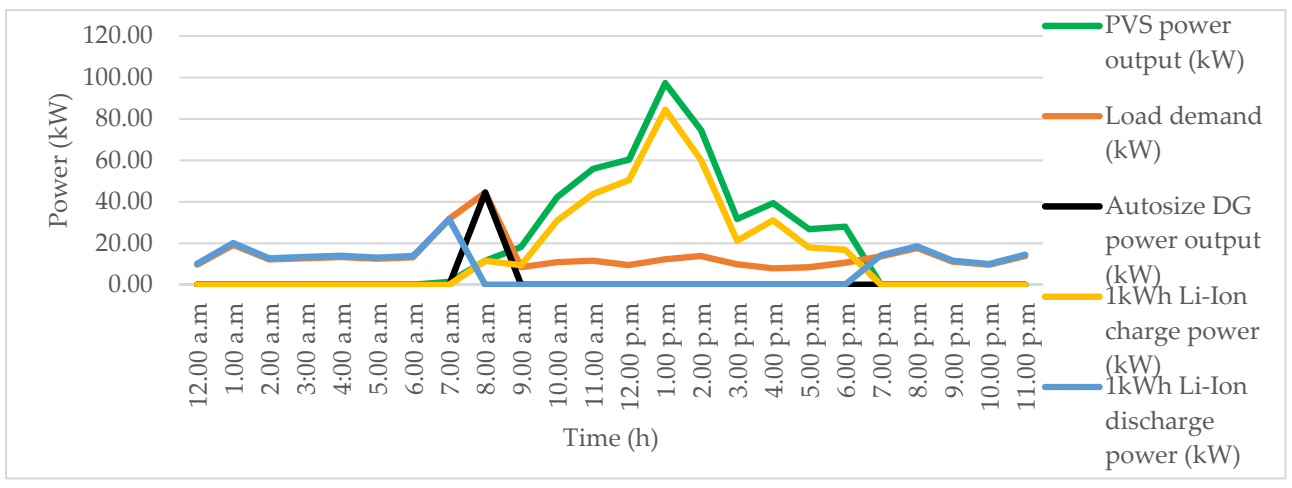

Figure 12. Daily time-stamped analysis for the month of October.

In Figure 13, the daily time-stamped analysis for the month of June using a solar DG source with TSVA tracking technique is shown. The hourly data for PVS output power, autosize DG power output, $1 \mathrm{kWh}$ Li-Ion charge power, $1 \mathrm{kWh}$ Li-Ion discharge power and load demand are recorded on 20 June. The month of June is the summer for Kalpeni Island and as such the 25 households used air conditioners more, while the use of the water geyser reduces significantly. From 10.00 p.m. to 11.00 p.m. and 12.00 a.m. to 2.00 a.m., the air conditioner is used so that the load demand is more between this period as shown in Figure 13. Due to insufficient solar radiation between 12.00 a.m. and 6.00 a.m., the Li-Ion battery discharges power from $12.00 \mathrm{a} . \mathrm{m}$. to $2.00 \mathrm{a} . \mathrm{m}$. and $4.00 \mathrm{a} . \mathrm{m}$. to $6.00 \mathrm{a} . \mathrm{m}$. and the diesel generator generated $51.21 \mathrm{~kW}$ power at 3.00 a.m. to satisfy the load demand. Between 7.00 a.m. and 8.00 a.m., PVS produces output between $9.08 \mathrm{~kW}$ and $27.40 \mathrm{~kW}$ and diesel generator produces $85 \mathrm{~kW}$ power output. The Li-ion battery is charged from the output of solar PVS and diesel generator during this period. Between 9:00 a.m. and 7:00 p.m., only the solar PVS is operated to satisfy the load demand while the diesel generator is not operated to avoid emission. The Li-Ion battery gets charged from 7.00 a.m. to 2.00 p.m. Finally, from 8.00 p.m. to 11.00 p.m., the Li-Ion battery discharges power. The discharging power is overlapping with the load demand from 12.00 a.m. to 2.00 a.m. and from 8.00 p.m. to 11.00 p.m.

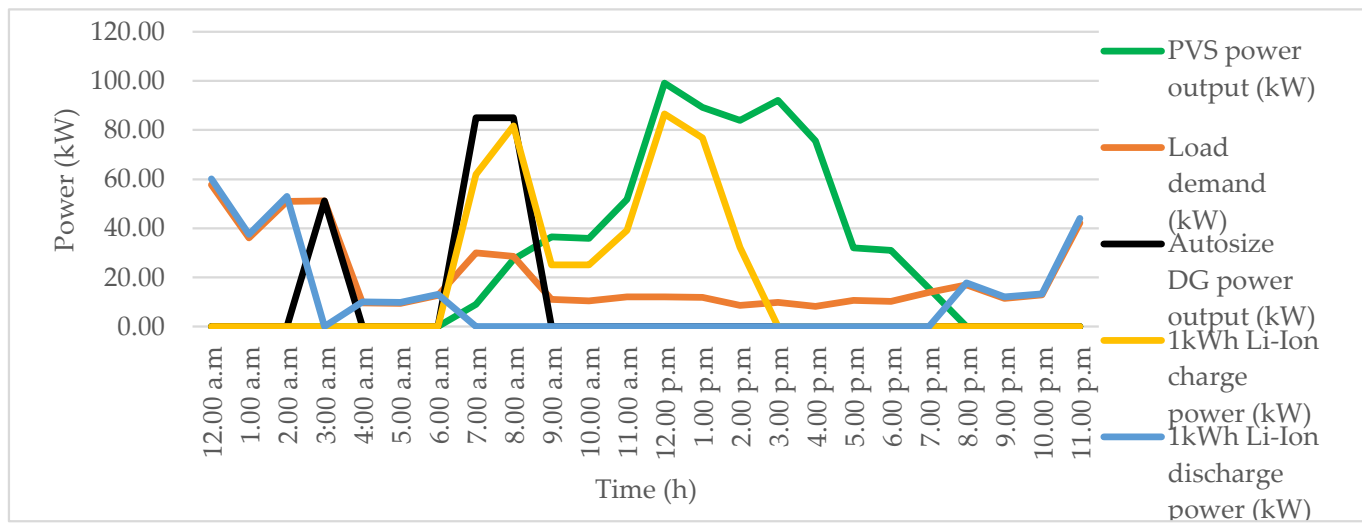

Figure 13. Daily time-stamped analysis for the month of June.

In Figure 14, the operation of inverter on 20 June using a solar DG source with TSVA tracking technique is shown. The inverter input is DC source and the output is AC source. The $1 \mathrm{kWh}$ Li-Ion battery SOC varies between 20\% and 100\%. The battery discharges till $20 \%$ only as per the constraints. When the battery discharges till $0 \%$ or less than $20 \%$, then it affects the lifetime of battery. The household and electric load-2 requires AC supply. 
Thus, to receive power from the photovoltaic system (PVS), a converter is essential to provide power to household and electric load-2 since the output of solar is DC supply. From 12.00 a.m. to 2.00 a.m., an inverter is operating based on a $1 \mathrm{kWh}$ Li-Ion battery discharge. The $60.10 \mathrm{~kW}, 37.60 \mathrm{~kW}$ and $53.06 \mathrm{~kW}$ discharge power of battery from 12.00 a.m. to 2.00 a.m. is given as input to the inverter as shown in Figure 14. The inverter input power and battery discharge are overlapped in Figure 14. Then, the inverter is operated from 4.00 a.m. to 6.00 a.m. based on $1 \mathrm{kWh}$ Li-Ion battery discharge. From 12.00 a.m. to 6.00 a.m., the solar panels can not generate power due to insufficient solar radiation, so the battery helps to satisfy the load demand through inverter. However, after $9.00 \mathrm{a}$.m. till 11.00 p.m., the operation of inverter is purely based on the output of PVS. The input power of inverter at $1.00 \mathrm{p} . \mathrm{m}$. is $12.42 \mathrm{~kW}$; then, the inverter output power is $11.93 \mathrm{~kW}$ since the inverter efficiency is $96 \%$. The excess power from photovoltaic system (PVS) for each hour is stored in the battery. Similarly, the inverter output power is evaluated every time, and it is connected to load demand to fulfil it.

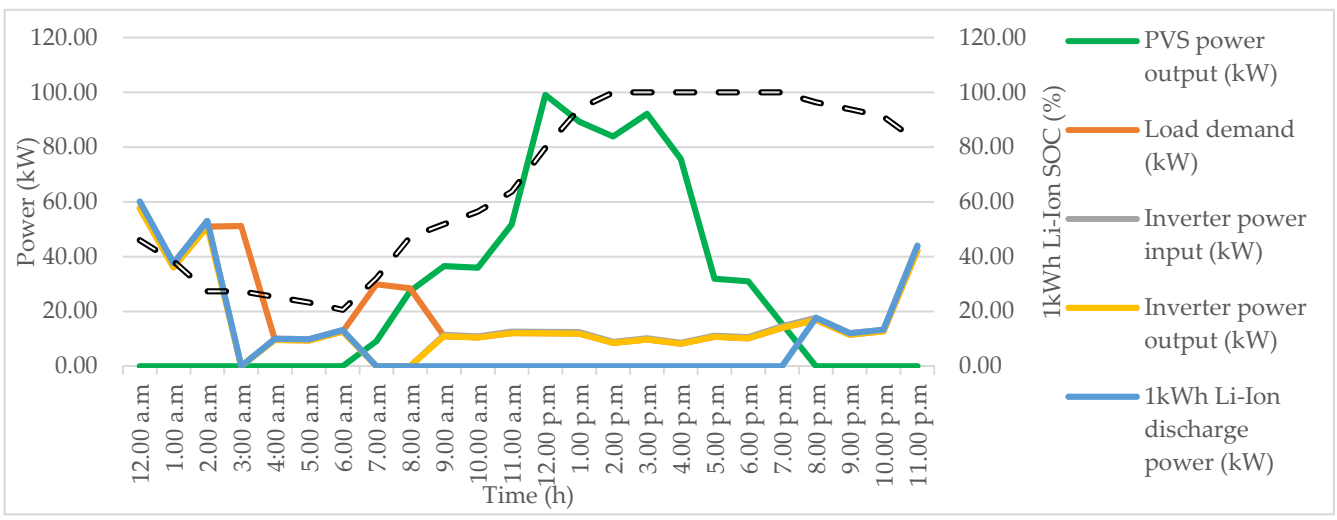

Figure 14. Inverter operation for the month of June.

In Figure 15, the operation of rectifier on 20 June using solar DG source with TSVA tracking technique is shown. The input and output of rectifier are AC and DC, respectively. The rectifier is operating only between 7.00 a.m. and 8.00 a.m. as shown in Figure 15. The rectifier is used to convert the AC input to DC output, which is connected to DC bus. The input and output power of rectifier at 7.00 a.m. are $55.07 \mathrm{~kW}$ and $52.87 \mathrm{~kW}$, respectively. At 8.00 a.m., the rectifier input and output power are $56.54 \mathrm{~kW}$ and $54.28 \mathrm{~kW}$, respectively. The diesel generator (DG) output from 7.00 a.m. to $8.00 \mathrm{a} . \mathrm{m}$. is $85 \mathrm{~kW}$. Since the output of DG is AC source, the rectifier receives $55.07 \mathrm{~kW}$ and $56.54 \mathrm{~kW}$ at 7.00 a.m. and 8.00 a.m., respectively, from the diesel generator. The battery SOC in \% shows the performance of battery during this period.
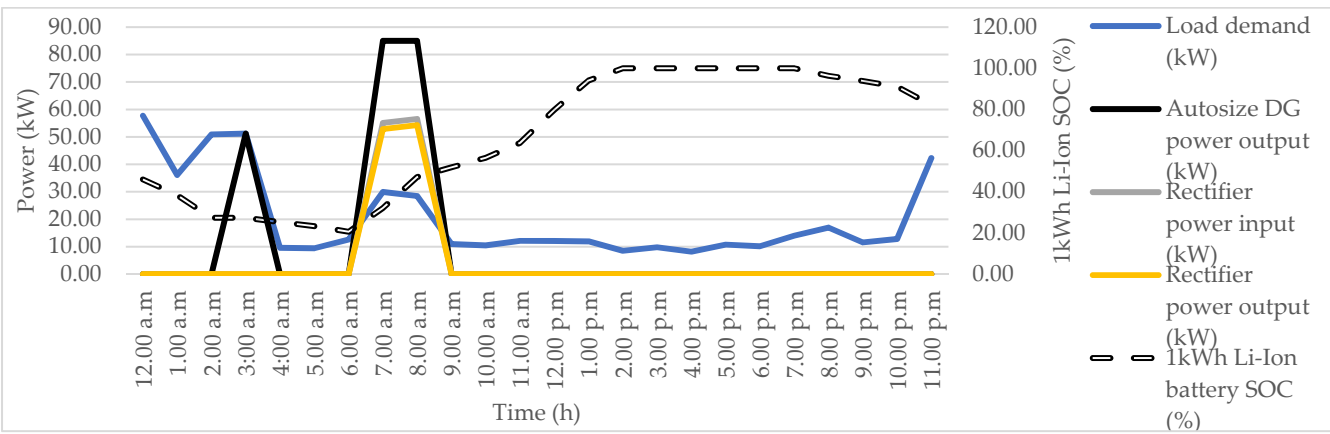

Figure 15. Rectifier operation for the month of June. 


\subsection{Multi-Year Analysis for Solar DG with TSVA}

Effect of Load Growth

The load will change every year as various appliances are used in residence and electric load-2. The domestic load growth for a period of 25 years is assumed to be $3 \%$, and, for electric load-2, load growth $2 \%$ is considered in this study. Search space given for solar PVS, wind turbine, battery and converter in HOMER are 0-136 kW, 0-50 kW, 0-512 kWh, $0-60.8 \mathrm{~kW}$, respectively.

In Figure 16, the variation of PVS generation (kWh/yr), DG generation $(\mathrm{kWh} / \mathrm{yr})$, energy out of battery $(\mathrm{kWh} / \mathrm{yr})$ and total emission $(\mathrm{kg} / \mathrm{yr})$ for a period of 25 years are shown. The diesel generator produces $23,065 \mathrm{kWh}$ during the first year. The usage of diesel generator increases every year to satisfy the load demand. Compared with the first year, the production of diesel generator is increased by $18.42 \%$ in the second year. The diesel generator produces $139,911 \mathrm{kWh}$ during the 25th year. The solar PVS power produces $252,789 \mathrm{kWh}$ every year. The energy out of the battery varies between $97,730 \mathrm{kWh} / \mathrm{yr}$ and $101,095 \mathrm{kWh} / \mathrm{yr}$ during the period of 25 years. The load consumption increases from $155,858 \mathrm{kWh} / \mathrm{yr}$ to $304,417 \mathrm{kWh} / \mathrm{yr}$ within a period of 25 years based on the input given to HOMER. The total emission produced during the first year is $18,646 \mathrm{~kg}$. The total emission increases each year due to an increase in diesel generator production to satisfy the varying load growth. During the 25th year, the diesel generator produces total emission of $111,097 \mathrm{~kg}$.

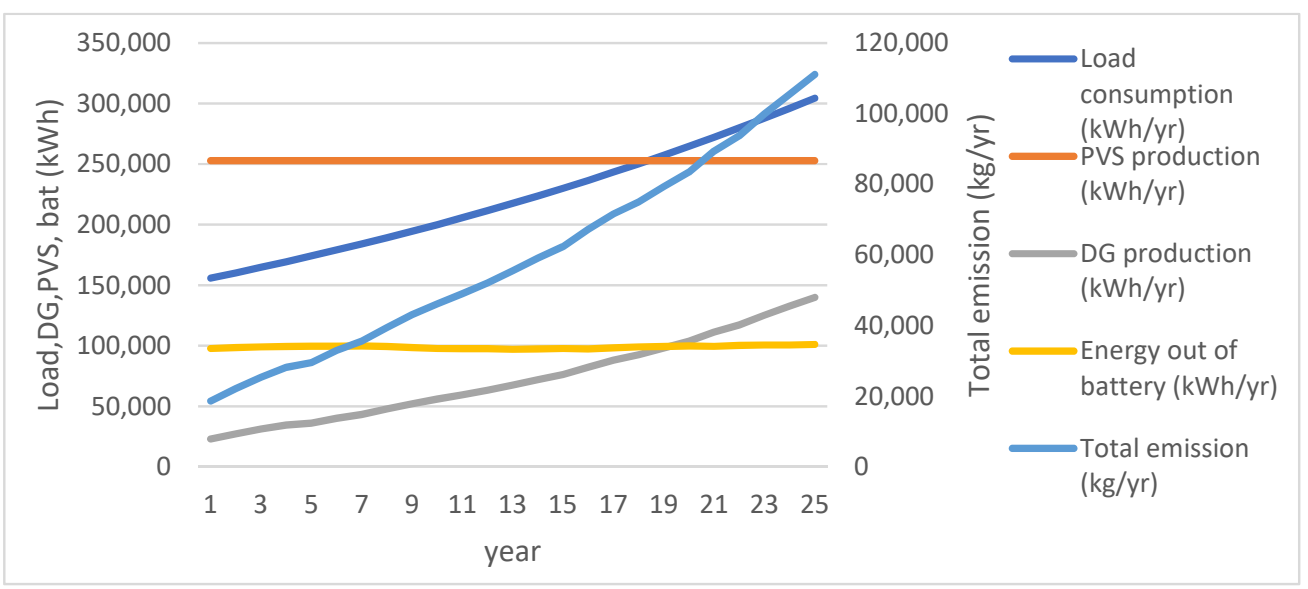

Figure 16. Variation of generation, load and total emission using a HOMER multi-year model.

In Figure 17, the load variation with renewable fraction and PVS penetration in a HOMER multi-year model is shown. The renewable fraction depends on DG power generation and load consumption. The renewable fraction for the first year is $85.2 \%$, and the renewable fraction decreases till the 25th year as shown in Figure 17a. The renewable fraction for the 25 th year is $54 \%$, which is less compared to the first year. For every year, as the load increases, the renewable fraction decreases. The PVS penetration is the ratio of mean output power of PVS to average load demand. For every year, as the load increases, the PVS penetration decreases as shown in Figure 17b. The PVS penetration decreases from $162 \%$ to $83 \%$ during the 25 -year load consumption. 


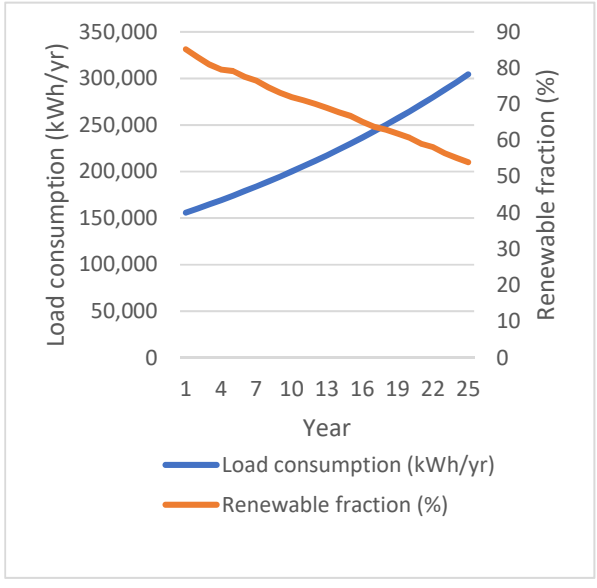

(a)

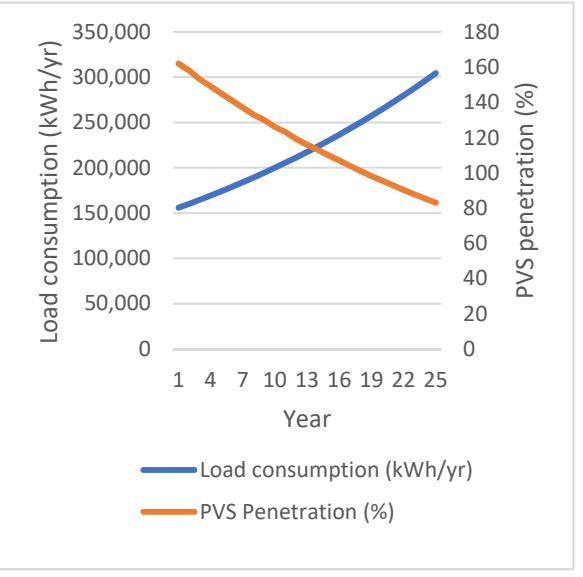

(b)

Figure 17. HOMER multi-year model (a) variation of load consumption with renewable fraction; (b) variation of load consumption with PVS penetration.

\subsection{Sensitivity Analysis for Solar DG with TSVA}

\subsubsection{Effect of Rising Diesel Price}

On Kalpeni Island, the diesel price varies between 1 \$/L and $1.2 \$ / \mathrm{L}$ during 2020 and 2021 with monthly variation. As per the diesel price history in India, the diesel price varies between 0.41 \$/L and 1.2 \$/L from the year 2007 to 2021. In this study, the diesel price variation is assumed as $5 \%$. Thus, to analyze the performance of the system, diesel price varies between $0.85 \$ / \mathrm{L}$ and $1.15 \$ / \mathrm{L}$ for performing sensitivity analysis. The net present cost is $\$ 440,579.6$ when diesel price is $0.85 \$ / \mathrm{L}, \$ 448,269$ when diesel price is $1 \$ / \mathrm{L}$ and $\$ 458,677$ when diesel price is $1.15 \$ / \mathrm{L}$. The net present cost varies according to diesel prices, which is also shown in Figure 18. Comparing the diesel prices $0.85 \$ / \mathrm{L}, 0.90 \$ / \mathrm{L}$ and $0.95 \$ / \mathrm{L}$ with $1 \$ / \mathrm{L}$, the net present cost $\left(\mathrm{C}_{\mathrm{NP}}\right)$ decreases to $1.71 \%, 0.98 \%$ and $0.42 \%$, respectively. Comparing the diesel prices 1.05 \$/L, 1.10 \$/L and 1.15 \$/L with 1 \$/L, the net present cost $\left(\mathrm{C}_{\mathrm{NP}}\right)$ increases to $0.85 \%, 1.67 \%$ and $2.32 \%$, respectively. The diesel power production and $\mathrm{CO}_{2}$ emission vary erratically when the diesel price is between $0.85 \$ / \mathrm{L}$ and 1.15 \$/L as shown in Figure 18. The diesel generator production and $\mathrm{CO}_{2}$ emission are recorded as the highest at $18,751.15 \mathrm{kWh} / \mathrm{yr}$ and $14,335.66 \mathrm{~kg} / \mathrm{yr}$ when diesel price is $0.95 \$ / \mathrm{L}$ due to a low renewable fraction of $88 \%$. The diesel generator production and $\mathrm{CO}_{2}$ emission are recorded as the lowest as $14,076.13 \mathrm{kWh} / \mathrm{yr}$ and 10,803.75 kg/yr when diesel price is $1.15 \$ / \mathrm{L}$ due to high renewable fraction of $91 \%$.

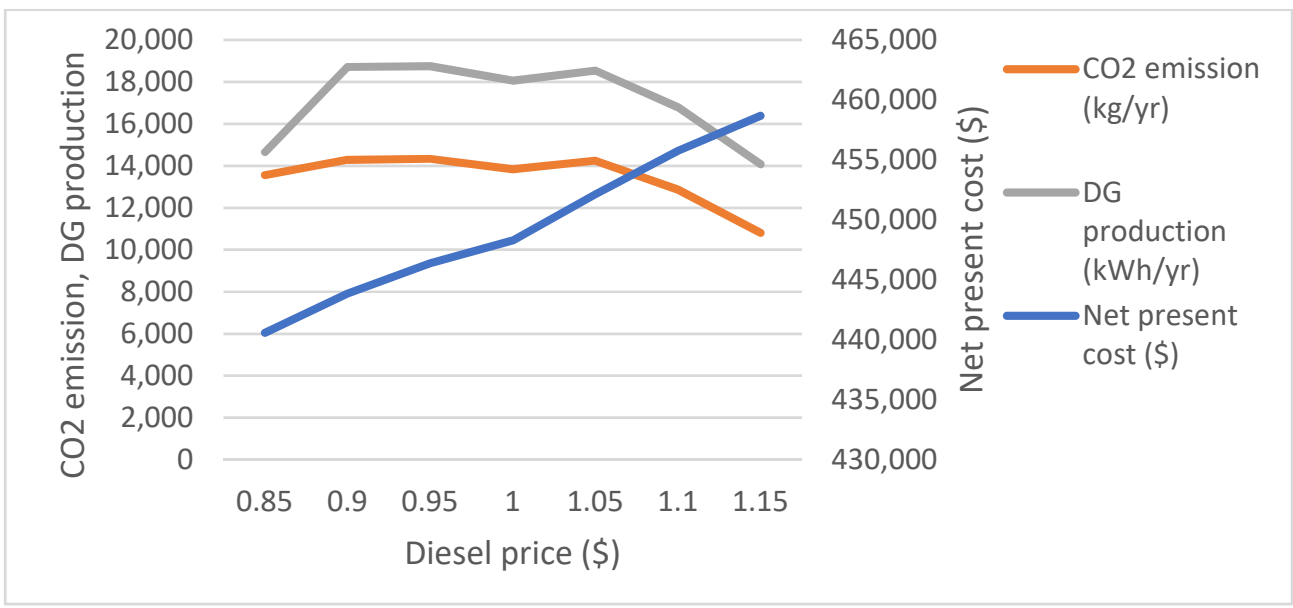

Figure 18. Effect of rising diesel price on $\mathrm{CO}_{2}$ emission, DG production and net present cost. 


\subsubsection{Effect of Rising Battery Minimum SOC}

The performance of hybrid PVS-DG system can be analyzed by increasing the minimum SOC of the battery. The battery minimum SOC is considered as $20 \%, 25 \%, 30 \%$ and $35 \%$ for analyzing sensitivity results.

Figure 19 shows the effect of rising battery $\mathrm{SOC}_{\min }$ on replacement cost of battery, net present cost and PVS penetration, PVS production and levelized energy cost. Since the battery should be replaced every eight years, the replacement cost of battery is significantly higher. The battery $\mathrm{SOC}_{\min }$ should be maintained at at least $20 \%$ to increase the lifetime of the battery and to avoid damaging the battery elements. When the system is required to discharge the battery below $20 \%$ for a particular time ' $t$ ', the system will operate with a diesel generator to satisfy the demand when there is insufficient solar output. The replacement cost of battery is $\$ 92,278.23$ when $\mathrm{SOC}_{\min }$ is $20 \%$ but at $25 \%, 30 \%$ and $35 \%$, the replacement cost of battery is $\$ 98,406, \$ 105,075$ and $\$ 111,202$, respectively. The replacement cost of battery is increased by $20.50 \%$ when $\mathrm{SOC}_{\min }$ of battery increased from $20 \%$ to $35 \%$. When the battery $\mathrm{SOC}_{\min }$ is $35 \%$, the battery will operate only from $100 \%$ to $35 \%$. As $\mathrm{SOC}_{\min }$ increases $(20-35 \%)$, the PVS penetration increases. When $\mathrm{SOC}_{\min }$ of battery is $20 \%$ and $25 \%$, then PVS penetration is $162 \%$. The PVS penetration increases to $165 \%$ and $170 \%$ when $\mathrm{SOC}_{\min }$ increased to $30 \%$ and $35 \%$. Similarly, there is an impact on rise in $\mathrm{SOC}_{\min }$ of battery on net present cost $\left(\mathrm{C}_{\mathrm{NP}}\right)$. The ' $\mathrm{C}_{\mathrm{NP}}$ ' increases from $\$ 448,269$ to $\$ 498,490$ when $\mathrm{SOC}_{\mathrm{min}}$ of battery is set from $20 \%$ to $35 \%$. The PVS production increases from $252,135 \mathrm{kWh} / \mathrm{yr}$ to $265,180 \mathrm{kWh} / \mathrm{yr}$ when $\mathrm{SOC}_{\min }$ of battery increased from $20 \%$ to $35 \%$. The levelized energy cost also increases from $0.222 \$ / \mathrm{kWh}$ to $0.247 \$ / \mathrm{kWh}$ when $\mathrm{SOC}_{\text {min }}$ of battery increases from $20 \%$ to $35 \%$.

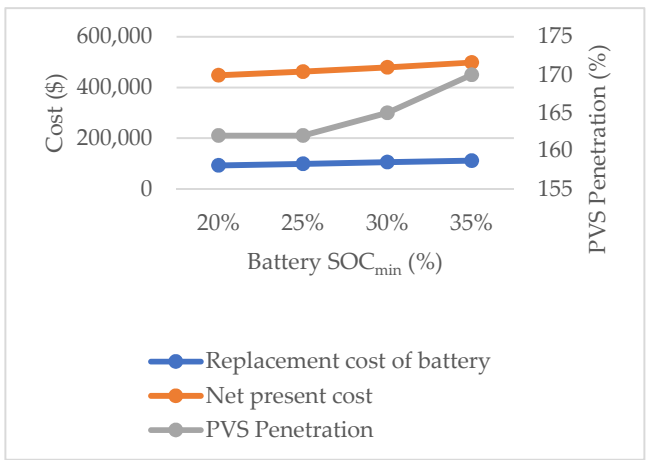

(a)

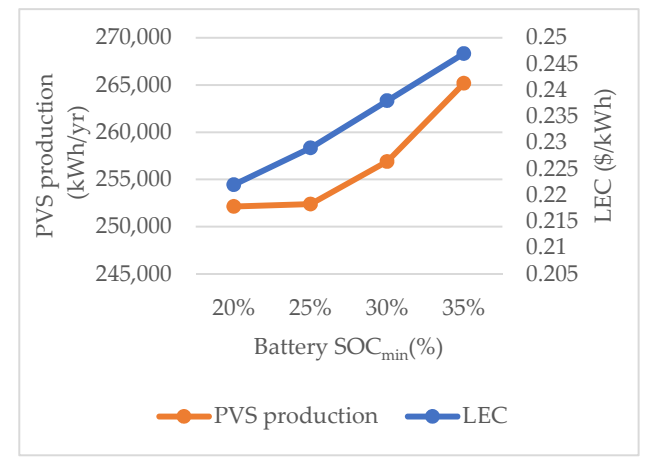

(b)

Figure 19. Effect of rising battery $\mathrm{SOC}_{\min }(\mathrm{a})$ effect of $\mathrm{SOC}_{\min }$ on replacement cost of battery, net present cost and PVS penetration; (b) effect of $\mathrm{SOC}_{\min }$ on PVS production and levelized energy cost.

\subsubsection{Effect of Rising PVS Derating}

The PVS derating is essential in estimating the output power of solar PVS ' $\mathrm{P}_{\mathrm{PVS}}$ '. The output of solar PVS is proportional to PVS derating. Practically, PVS derating cannot be $100 \%$ due to several factors. While fixing the solar panels on Kalpeni Island, the PVS derating depends mainly on shading effect, wiring loss, deposition of soil over the solar panel layer, etc. Thus, the PVS derating factor ' $\mathrm{D}_{\mathrm{F}}$ ' is assumed to be $84 \%$ and $88 \%$ to analyze the performance of the studied area.

Figure 20a shows the effect of $84 \%$ and $88 \%$ PVS derating for PVS production and levelized energy cost, and Figure 20b shows the effect of $84 \%$ and $88 \%$ PVS derating for capital cost of PVS, net present cost and levelized energy cost. The result shows that the PVS production increases when PVS derating increases. The PVS production is $251,004 \mathrm{kWh} / \mathrm{yr}$ when PVS derating is $84 \%$, but it increases to $251,577 \mathrm{kWh} / \mathrm{yr}$ when the derating factor is considered as $88 \%$. The levelized energy cost (LEC) reduced from $0.221 \$ / \mathrm{kWh}$ to $0.218 \$ / \mathrm{kWh}$ when the PVS derating factor is increased from $84 \%$ to $88 \%$. All cost parameters (levelized energy cost, net present cost, capital cost of PVS) decreases 
when PVS derating increases as shown in Figure 20b. The net present cost decreases from $\$ 444,689$ to $\$ 439,564$ and capital cost of PVS decreases from $\$ 95,171$ to $\$ 91,052$ when PVS derating is increased from $84 \%$ to $88 \%$.

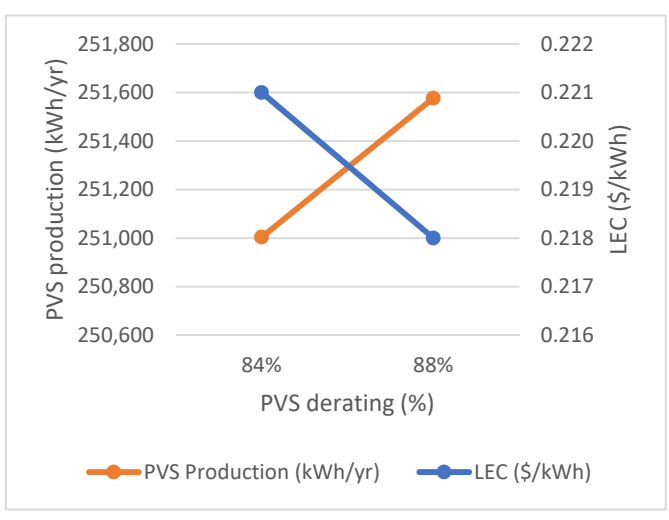

(a)

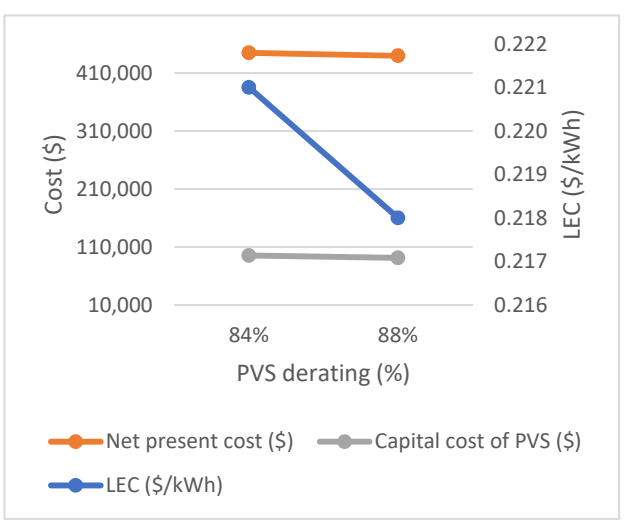

(b)

Figure 20. Effect of rising PVS derating (a) Effect of $84 \%$ and $88 \%$ PVS derating for PVS production and levelized energy cost (LEC); (b) effect of $84 \%$ and $88 \%$ PVS derating for capital cost of PVS, net present cost and levelized energy cost (LEC).

\subsubsection{Effect of Rising Photovoltaic Cell Temperature}

The sensitivity analysis performed for different photovoltaic cell temperature ' $\mathrm{T}_{\mathrm{PVC}}$ ' is shown in Figure 21. The net present cost $\left(C_{N P}\right)$ increases from $\$ 452,219$ to $\$ 455,041.3$ when photovoltaic cell temperature is increased from $38{ }^{\circ} \mathrm{C}$ to $44{ }^{\circ} \mathrm{C}$. Similarly, the levelized energy cost (LEC) increases from $0.2244 \$ / \mathrm{kWh}$ to $0.2258 \$ / \mathrm{kWh}$ considering the above temperature change. When the photovoltaic cell temperature is increased from $38^{\circ} \mathrm{C}$ to $40{ }^{\circ} \mathrm{C}$, then $0.48 \%$ of net present cost is increased. Likewise, from $40{ }^{\circ} \mathrm{C}$ to $42{ }^{\circ} \mathrm{C}, 0.06 \%$ of net present cost is increased and, from $42{ }^{\circ} \mathrm{C}$ to $44{ }^{\circ} \mathrm{C}, 0.07 \%$ of net present cost is increased. Thus, the change in photovoltaic cell temperature has an impact on cost parameters.

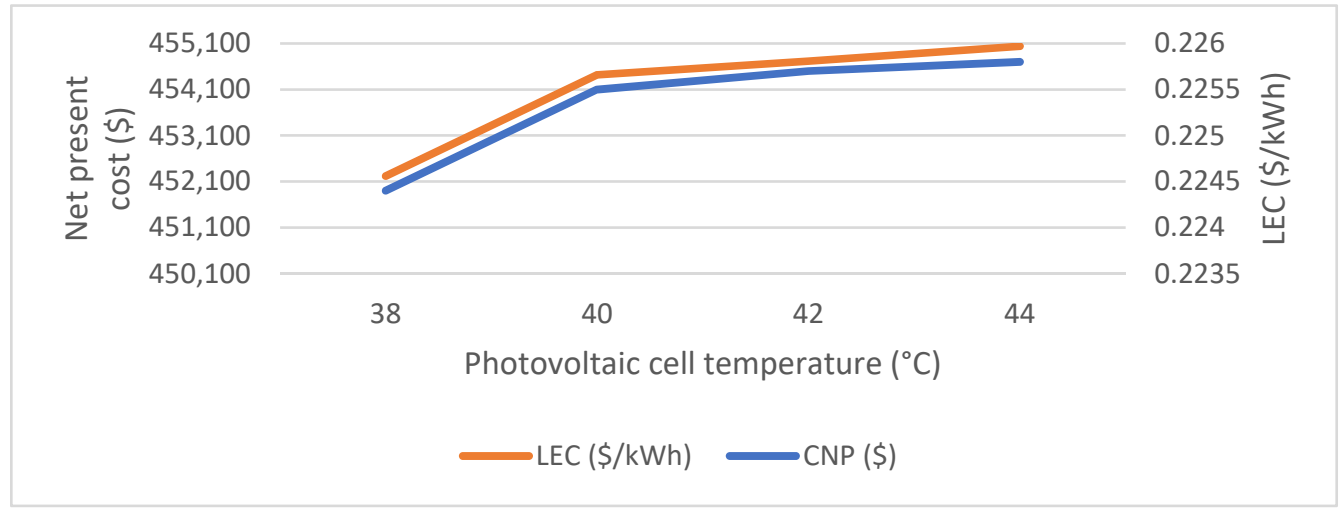

Figure 21. Effect of rising photovoltaic cell temperature on LEC and net present cost.

\subsubsection{Effect of Changing Inverter and Rectifier Efficiency}

This section discusses the effect of inverter and rectifier efficiency on net present cost, PVS power production, loss of generation probability and expected energy not served.

In Figure 22, the variations of net present cost considering the fluctuation of inverter and rectifier efficiency are shown. The values entered inside the surface plot are PVS power production. The PVS power production for the system (solar DG with TSVA) operating with $96 \%$ rectifier and $96 \%$ inverter efficiency is $252,135 \mathrm{kWh} / \mathrm{yr}$. However, when there are changes in efficiency for inverter and rectifier, then the PVS power production changes. When efficiency increases to $98 \%$, the PVS power production is $243,676 \mathrm{kWh} / \mathrm{yr}$. The net 
present cost ' $\mathrm{C}_{\mathrm{NP}}$ ' is less when the converter (inverter and rectifier) efficiency is maintained between $96 \%$ and $98 \%$ but increases when the efficiency reduced to $95 \%$ to $96 \%$.

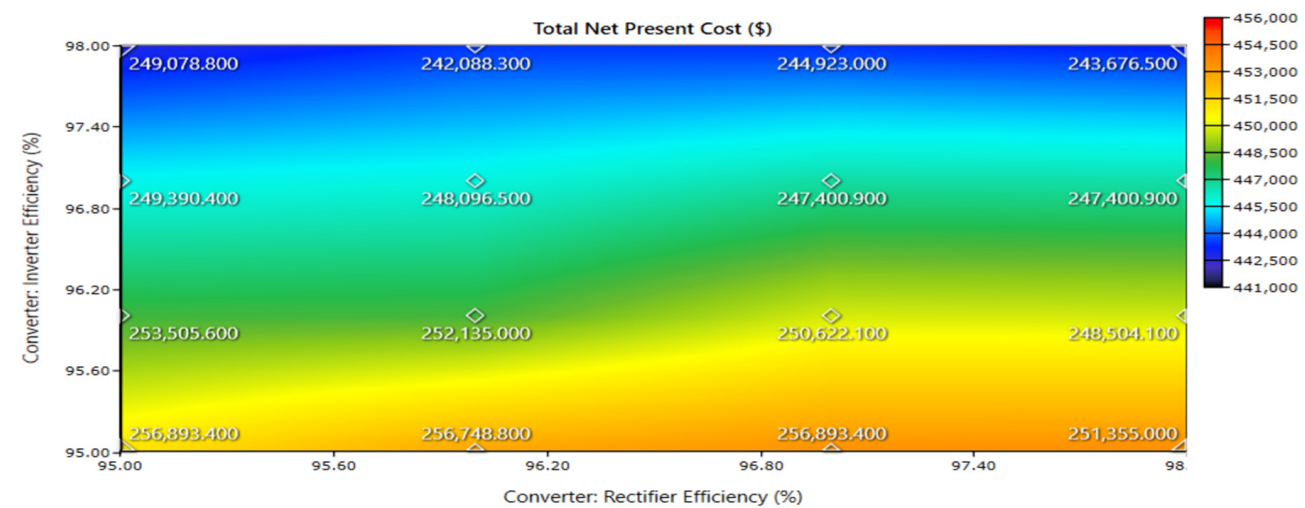

Figure 22. Variation of net present cost considering fluctuation of inverter and rectifier efficiency (superimposed: PVS power production).

In Figure 23, the variation of loss of generation probability (LGP) considering the fluctuation of inverter and rectifier efficiency is shown. The values entered inside the surface plot are expected energy not served (ENS). When the inverter and rectifier efficiency are $96 \%$ (Solar DG with TSVA), then the ENS is $50.3 \mathrm{kWh} / \mathrm{yr}$. When the efficiency decreases, the ENS and LGP increases. The ENS is $74.82 \mathrm{kWh} / \mathrm{yr}$ when rectifier efficiency is $96 \%$ and inverter efficiency is $95 \%$. When rectifier efficiency is $96 \%$ and inverter efficiency is $97 \%$, then the ENS is $31.10 \mathrm{kWh} / \mathrm{yr}$. From the surface plot, it is understood that, when the inverter and rectifier efficiency are high, then reliability is improved. From the surface plot, there is no loss of generation probability (LGP) when the inverter and rectifier efficiency are $96 \%$ and $97 \%$, respectively.

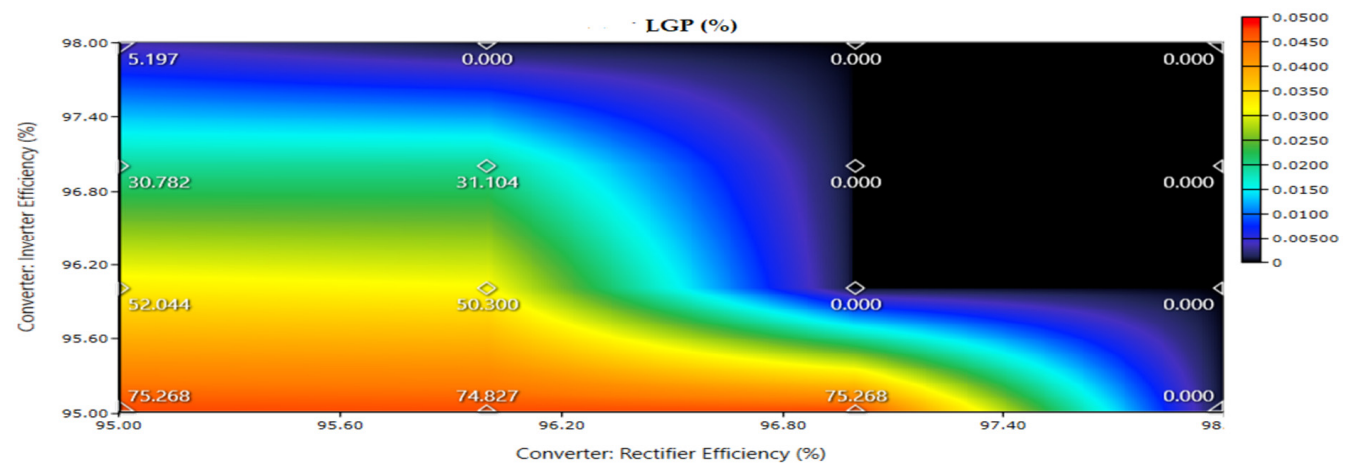

Figure 23. Variation of LGP considering fluctuation of inverter and rectifier efficiency (superimposed: ENS).

\section{Conclusions}

The standalone solar/DG, wind/DG, solar/wind/DG and solar/wind with fixed system without tracking (FSWT), tracking system on a horizonal axis (TSHA), tracking system on a vertical axis (TSVA) and tracking system on dual axis (TSDA) were analyzed and compared using HOMER software based on the estimated load profile for residential and load profile for commercial with street lights and environmental conditions of Kalpeni Island. The best optimization result shows that the solar photovoltaic system (PVS) with a tracking system on a vertical axis and diesel generator are the suitable sources to meet the electricity demand with low levelized energy cost (LEC) of $0.222 \$ / \mathrm{kWh}$ on Kalpeni Island. When compared to FSWT, 10.73\% power production is increased in PVS/DG, $9.77 \%$ is increased in PVS/WT/DG and $10.35 \%$ is increased in PVS/WT while using TSVA. The different multi-year and sensitivity analysis like effects of load growth, diesel price, 
battery minimum SOC, PVS derating, photovoltaic cell temperature, changing inverter and converter efficiency are performed.

From multi-year analysis, the renewable fraction for the 25 th year is $54 \%$, which is less when compared to the first year. Compared with the first year, the production of diesel generator increased by $506.59 \%$ to satisfy the future load demand on the 25 th year based on multi-year input given to HOMER.

Comparing the diesel prices $0.85 \$ / \mathrm{L}, 0.90 \$ / \mathrm{L}$ and $0.95 \$ / \mathrm{L}$ with 1 \$/L, the net present cost $\left(\mathrm{C}_{\mathrm{NP}}\right)$ decreases to $1.71 \%, 0.98 \%$ and $0.42 \%$, respectively. The replacement cost of battery is increased by $20.50 \%$ when $S C_{\min }$ of battery increased from $20 \%$ to $35 \%$. The $\mathrm{C}_{\mathrm{NP}}$ of battery is increased by $11.20 \%$ when $\mathrm{SOC}_{\min }$ of battery increased from $20 \%$ to $35 \%$. The LEC also increases from $0.222 \$ / \mathrm{kWh}$ to $0.247 \$ / \mathrm{kWh}$ when $\mathrm{SOC}_{\min }$ of battery increases from $20 \%$ to $35 \%$. The PVS power production is increased by $0.228 \%$ when PVS derating increases from $84 \%$ to $88 \%$. The LEC reduced from $0.221 \$ / \mathrm{kWh}$ to $0.218 \$ / \mathrm{kWh}$ when PVS derating factor is increased from $84 \%$ to $88 \%$. The $\mathrm{C}_{\mathrm{NP}}$ and capital cost of PVS reduces by $1.152 \%$ and $4.32 \%$, respectively, when PVS derating increases from $84 \%$ to $88 \%$. When photovoltaic cell temperature is increased from $38^{\circ} \mathrm{C}$ to $44{ }^{\circ} \mathrm{C}, \mathrm{C}_{\mathrm{NP}}$ is increased by $0.62 \%$ and, when increased from $38{ }^{\circ} \mathrm{C}$ to $44{ }^{\circ} \mathrm{C}$, LEC is increased by $0.61 \%$. The $\mathrm{C}_{\mathrm{NP}}$ is less when the inverter and rectifier efficiency is maintained between $96 \%$ and $98 \%$. There is no loss of generation probability (LGP) when the inverter and rectifier efficiency are $96 \%$ and $97 \%$, respectively, in the system operating with solar DG with TSVA on Kalpeni Island. For future research, additional sources can be incorporated into the system located on Kalpeni Island to analyze the performance in terms of levelized energy cost and reliability indices. Furthermore, several regions with different sunlight conditions could be compared for analyzing an efficient microgrid system. To summarize, these results will be helpful in motivating stakeholders of renewable energy to build similar initiatives in order to generate power at a cheap cost with minimal emissions for islands.

Author Contributions: Methodology, software, writing —original draft preparation, V.J.P.; supervision, writing-review and editing, P.K.D. All authors have read and agreed to the published version of the manuscript.

Funding: This research received no external funding.

Institutional Review Board Statement: Not applicable.

Informed Consent Statement: Not applicable.

Data Availability Statement: Not applicable.

Conflicts of Interest: The authors declare no conflict of interest.

\section{References}

1. India-Cumulative Installed Power Capacity Mix (\%). Available online: https://mercomindia.com/wp-content/uploads/2020/0 4/India-Cumulative-Installed-Power-Capacity-Mix.png (accessed on 27 September 2021).

2. Xie, J.; Zheng, Y.; Pan, X.; Zheng, Y.; Zhang, L.; Zhan, Y. A Short-Term Optimal Scheduling Model for Wind-Solar-Hydro Hybrid Generation System with Cascade Hydropower Considering Regulation Reserve and Spinning Reserve Requirements. IEEE Access 2021, 9, 10765-10777. [CrossRef]

3. Bandoc, G.; Florescu, A.-M.S.; Degeratu, M.; Pravalie, R. Use of hybrid renewable energy systems for small communities. Renew. Energy Environ. Sustain. 2016, 1, 29. [CrossRef]

4. Kharrich, M.; Kamel, S.; Abdeen, M.; Mohammed, O.H.; Akherraz, M.; Khurshaid, T.; Rhee, S.-B. Developed Approach Based on Equilibrium Optimizer for Optimal Design of Hybrid PV/Wind/Diesel/Battery Microgrid in Dakhla, Morocco. IEEE Access 2021, 9, 13655-13670. [CrossRef]

5. Ahmed, M.; Meegahapola, L.; Vahidnia, A.; Datta, M. Stability and Control Aspects of Microgrid Architectures-A Comprehensive Review. IEEE Access 2020, 8, 144730-144766. [CrossRef]

6. Al-Ismail, F.S. DC Microgrid Planning, Operation, and Control: A Comprehensive Review. IEEE Access 2021, 9, $36154-36172$. [CrossRef]

7. Wild, J.; Boutin, V.; Barton, P.; Haines, L. Microgrid Benefits and Example Projects; Schneider Electric: Paris, France, 2016.

8. Arkhangelski, J.; Abdou-Tankari, M.; Lefebvre, G. Day-Ahead Optimal Power Flow for Efficient Energy Management of Urban Microgrid. IEEE Trans. Ind. Appl. 2021, 57, 1285-1293. [CrossRef] 
9. Pacheco, F.E.; Foreman, J.C. Microgrid Reference Methodology for Understanding Utility and Customer Interactions in Mi-crogrid Projects. Electr. J. 2017, 30, 44-50.

10. Vaahedi, E.; Nodehi, K.; Heim, D.; Rahimi, F.; Ipakchi, A. The Emerging Transactive Microgrid Controller: Illustrating Its Concept, Functionality, and Business Case. IEEE Power Energy Mag. 2017, 15, 80-87. [CrossRef]

11. Carpintero-Rentería, M.; Santos-Martín, D.; Guerrero, J.M. Microgrids Literature Review through a Layers Structure. Energies 2019, 12, 4381. [CrossRef]

12. Al-Ghussain, L.; Ahmad, A.D.; Abubaker, A.M.; Mohamed, M.A. An integrated photovoltaic/wind/biomass and hybrid energy storage systems towards $100 \%$ renewable energy microgrids in university campuses. Sustain. Energy Technol. Assess. 2021, 46, 101273. [CrossRef]

13. Mostafaeipour, A.; Rezayat, H.; Rezaei, M. A thorough investigation of solar-powered hydrogen potential and accurate location planning for big cities: A case study. Int. J. Hydrogen Energy 2020, 45, 31599-31611. [CrossRef]

14. Rezaei, M.; Mostafaeipour, A.; Jafari, N.; Naghdi-Khozani, N.; Moftakharzadeh, A. Wind and solar energy utilization for seawater desalination and hydrogen production in the coastal areas of southern Iran. J. Eng. Des. Technol. 2020, 18, 1951-1969. [CrossRef]

15. Kong, X.; Liu, X.; Ma, L.; Lee, K.Y. Hierarchical Distributed Model Predictive Control of Standalone Wind/Solar/Battery Power System. IEEE Trans. Syst. Man Cybern. Syst. 2019, 49, 1570-1581. [CrossRef]

16. Adetunji, K.E.; Akinlabi, O.; Joseph, M.K. Developing a Microgrid for Tafelkop Using HOMER. In Proceedings of the 2018 International Conference on Advances in Big Data, Computing and Data Communication Systems (icABCD), Durban, South Africa, 6-7 August 2018; pp. 1-6. [CrossRef]

17. Nurunnabi, M.; Roy, N.K.; Hossain, E.; Pota, H.R. Size Optimization and Sensitivity Analysis of Hybrid Wind/PV Micro-Grids-A Case Study for Bangladesh. IEEE Access 2019, 7, 150120-150140. [CrossRef]

18. Menicou, M.; Exizidou, P.; Vassiliou, V.; Christou, P. An economic analysis of Cyprus 'residential buildings' energy ret-rofits potential. Int. J. Sustain. Energy 2015, 34, 166-187. [CrossRef]

19. Vuyyuru, U.; Maiti, S.; Chakraborty, C. Active Power Flow Control between DC Microgrids. IEEE Trans. Smart Grid 2019, 10, 5712-5723. [CrossRef]

20. Kumar, P.; Pukale, R.; Kumabhar, N.; Patil, U. Optimal Design Configuration Using HOMER. Procedia Technol. 2016, 24, 499-504. [CrossRef]

21. Pookoya, C.G. Kalpeni Island: History, People and Culture, 1st ed.; Notion Press: Kalpeni Island, India, 2018 ; pp. 2-10.

22. Sinha, S.; Chandel, S. Review of software tools for hybrid renewable energy systems. Renew. Sustain. Energy Rev. 2014, 32, 192-205. [CrossRef]

23. Tribioli, L.; Cozzolino, R. Techno-economic analysis of a stand-alone microgrid for a commercial building in eight different climate zones. Energy Convers. Manag. 2018, 179, 58-71. [CrossRef]

24. Çetinbaş, I.; Tamyürek, B.; Demirtaş, M. Design, Analysis and Optimization of a Hybrid Microgrid System Using HOMER Software: Eskişehir Osmangazi University Example. Int. J. Renew. Energy Dev. 2019, 8, 65-79. [CrossRef]

25. Kumar Garg, V.; Sharma, S. Optimum Sizing and Economic Assessment of Hybrid Microgrid for Domestic Load Under Various Scenario. Int. J. Renew. Energy Res. 2021, 11, 235-246.

26. Akinyele, D. Analysis of photovoltaic mini-grid systems for remote locations: A techno-economic approach. Int. J. Energy Res. 2017, 42, 1363-1380. [CrossRef]

27. Al-Ammar, E.A.; Habib, H.U.R.; Kotb, K.M.; Wang, S.; Ko, W.; Elmorshedy, M.F.; Waqar, A. Residential Community Load Management Based on Optimal Design of Standalone HRES With Model Predictive Control. IEEE Access 2020, 8, 12542-12572. [CrossRef]

28. Vera, Y.E.G.; Dufo-López, R.; Bernal-Agustín, J.L. Energy Management in Microgrids with Renewable Energy Sources: A Literature Review. Appl. Sci. 2019, 9, 3854. [CrossRef]

29. Chambon, C.L.; Karia, T.; Sandwell, P.; Hallett, J.P. Techno-economic assessment of biomass gasification-based mini-grids for productive energy applications: The case of rural India. Renew. Energy 2020, 154, 432-444. [CrossRef]

30. Guo, Y.; Li, S.; Li, C.; Peng, H. Short-Term Reliability Assessment for Islanded Microgrid Based on Time-Varying Probability Ordered Tree Screening Algorithm. IEEE Access 2019, 7, 37324-37333. [CrossRef]

31. Peyghami, S.; Palensky, P.; Blaabjerg, F. An Overview on the Reliability of Modern Power Electronic Based Power Systems. IEEE Open J. Power Electron. 2020, 1, 34-50. [CrossRef]

32. Patowary, M.; Panda, G.; Deka, B.C. Reliability Modeling of Microgrid System Using Hybrid Methods in Hot Standby Mode. IEEE Syst. J. 2019, 13, 3111-3119. [CrossRef]

33. Baghaee, H.; Mirsalim, M.; Gharehpetian, G.; Talebi, H. Reliability/cost-based multi-objective Pareto optimal design of standalone wind/PV/FC generation microgrid system. Energy 2016, 115, 1022-1041. [CrossRef]

34. Priyadharshini, B.; Ganapathy, V.; Sudhakara, P. An Optimal Model to Meet the Hourly Peak Demands of a Specific Region with Solar, Wind, and Grid Supplies. IEEE Access 2020, 8, 13179-13194. [CrossRef]

35. Ali, T.; Ma, H.; Nahian, A.J. Techno-Economic Analysis of a Hybrid Mini-grid in Rural Areas: A Case Study of Bangladesh. J. Energy Res. Rev. 2020, 4, 10-29. [CrossRef]

36. Ahmad, S.; Ullah, I.; Jamil, F.; Kim, D. Toward the Optimal Operation of Hybrid Renewable Energy Resources in Microgrids. Energies 2020, 13, 5482. [CrossRef] 
37. Lee, H.-J.; Vu, B.H.; Zafar, R.; Hwang, S.-W.; Chung, I.-Y. Design Framework of a Stand-Alone Microgrid Considering Power System Performance and Economic Efficiency. Energies 2021, 14, 457. [CrossRef]

38. Alturki, F.A.; Awwad, E.M. Sizing and Cost Minimization of Standalone Hybrid WT/PV/Biomass/Pump-Hydro Storage-Based Energy Systems. Energies 2021, 14, 489. [CrossRef]

39. Hinokuma, T.; Farzaneh, H.; Shaqour, A. Techno-Economic Analysis of a Fuzzy Logic Control Based Hybrid Renewable Energy System to Power a University Campus in Japan. Energies 2021, 14, 1960. [CrossRef]

40. Riou, M.; Dupriez-Robin, F.; Grondin, D.; Le Loup, C.; Benne, M.; Tran, Q. Multi-Objective Optimization of Autonomous Microgrids with Reliability Consideration. Energies 2021, 14, 4466. [CrossRef]

41. Fathy, A.; Kaaniche, K.; Alanazi, T.M. Recent Approach Based Social Spider Optimizer for Optimal Sizing of Hybrid $\mathrm{PV} /$ Wind/Battery/Diesel Integrated Microgrid in Aljouf Region. IEEE Access 2020, 8, 57630-57645. [CrossRef]

42. Yu, Z.-X.; Li, M.-S.; Xu, Y.-P.; Aslam, S.; Li, Y.-K. Techno-Economic Planning and Operation of the Microgrid Considering Real-Time Pricing Demand Response Program. Energies 2021, 14, 4597. [CrossRef]

43. Odou, O.D.T.; Bhandari, R.; Adamou, R. Hybrid off-grid renewable power system for sustainable rural electrification in Benin. Renew. Energy 2020, 145, 1266-1279. [CrossRef]

44. Yahyaoui, I.; Atieh, A.; Serna, A.; Tadeo, F. Sensitivity analysis for photovoltaic water pumping systems: Energetic and eco-nomic studies. Energy Convers. Manag. 2017, 135, 402-415. [CrossRef]

45. Halabi, L.M.; Mekhilef, S.; Olatomiwa, L.; Hazelton, J. Performance analysis of hybrid PV/diesel/battery system using HOMER: A case study Sabah, Malaysia. Energy Convers. Manag. 2017, 144, 322-339. [CrossRef]

46. Veilleux, G.; Potisat, T.; Pezim, D.; Ribback, C.; Ling, J.; Krysztofiński, A.; Ahmed, A.; Papenheim, J.; Pineda, A.M.; Sembian, S.; et al. Techno-economic analysis of microgrid projects for rural electrification: A systematic approach to the redesign of Koh Jik off-grid case study. Energy Sustain. Dev. 2020, 54, 1-13. [CrossRef]

47. Dhundhara, S.; Verma, Y.P.; Williams, A. Techno-economic analysis of the lithium-ion and lead-acid battery in microgrid systems. Energy Convers. Manag. 2018, 177, 122-142. [CrossRef]

48. Rashid, F.; Hoque, E.; Aziz, M.; Sakib, T.N.; Islam, T.; Robin, R.M. Investigation of Optimal Hybrid Energy Systems Using Available Energy Sources in a Rural Area of Bangladesh. Energies 2021, 14, 5794. [CrossRef]

49. Phan, B.C.; Lai, Y.-C. Control Strategy of a Hybrid Renewable Energy System Based on Reinforcement Learning Approach for an Isolated Microgrid. Appl. Sci. 2019, 9, 4001. [CrossRef]

50. Beza, T.; Wu, C.-H.; Kuo, C.-C. Optimal Sizing and Techno-Economic Analysis of Minigrid Hybrid Renewable Energy System for Tourist Destination Islands of Lake Tana, Ethiopia. Appl. Sci. 2021, 11, 7085. [CrossRef]

51. Cai, G.; Kong, L. Techno-economic analysis of wind curtailment/hydrogen production/fuel cell vehicle system with high wind penetration in China. CSEE J. Power Energy Syst. 2017, 3, 44-52. [CrossRef]

52. Lu, J.; Wang, W.; Zhang, Y.; Cheng, S. Multi-Objective Optimal Design of Stand-Alone Hybrid Energy System Using Entropy Weight Method Based on HOMER. Energies 2017, 10, 1664. [CrossRef]

53. Singh, S.; Chauhan, P.; Aftab, M.A.; Ali, I.; Hussain, S.M.S.; Ustun, T.S. Cost Optimization of a Stand-Alone Hybrid Energy System with Fuel Cell and PV. Energies 2020, 13, 1295. [CrossRef]

54. Katsivelakis, M.; Bargiotas, D.; Daskalopulu, A.; Panapakidis, I.; Tsoukalas, L. Techno-Economic Analysis of a Stand-Alone Hybrid System: Application in Donoussa Island, Greece. Energies 2021, 14, 1868. [CrossRef]

55. Mun, H.; Moon, B.; Park, S.; Yoon, Y. A Study on the Economic Feasibility of Stand-Alone Microgrid for Carbon-Free Island in Korea. Energies 2021, 14, 1913. [CrossRef]

56. Nasab, N.M.; Kilby, J.; Bakhtiaryfard, L. Case Study of a Hybrid Wind and Tidal Turbines System with a Microgrid for Power Supply to a Remote Off-Grid Community in New Zealand. Energies 2021, 14, 3636. [CrossRef]

57. Nazir, R.; Laksono, H.; Waldi, E.; Ekaputra, E.; Coveria, P. Renewable Energy Sources Optimization: A Micro-Grid Model Design. Energy Procedia 2014, 52, 316-327. [CrossRef]

58. Murty, V.V.V.S.N.; Kumar, A. Optimal Energy Management and Techno-economic Analysis in Microgrid with Hybrid Renewable Energy Sources. J. Mod. Power Syst. Clean Energy 2020, 8, 929-940. [CrossRef]

59. Mas'Ud, A.; Al-Garni, H. Optimum Configuration of a Renewable Energy System Using Multi-Year Parameters and Advanced Battery Storage Modules: A Case Study in Northern Saudi Arabia. Sustainability 2021, 13, 5123. [CrossRef]

60. Iqbal, F.; Siddiqui, A.S. Optimal configuration analysis for a campus microgrid-A case study. Prot. Control Mod. Power Syst. 2017, 2, 23. [CrossRef]

61. Sadat, S.A.; Faraji, J.; Babaei, M.; Ketabi, A. Techno-economic comparative study of hybrid microgrids in eight climate zones of Iran. Energy Sci. Eng. 2020, 8, 3004-3026. [CrossRef]

62. Rousis, A.O.; Tzelepis, D.; Konstantelos, I.; Booth, C.; Strbac, G. Design of a Hybrid AC/DC Microgrid Using HOMER Pro: Case Study on an Islanded Residential Application. Inventions 2018, 3, 55. [CrossRef]

63. Olatomiwa, L.; Mekhilef, S.; Huda, A.S.N.; Sanusi, K. Techno-economic analysis of hybrid PV-diesel-battery and PV-winddiesel-battery power systems for mobile BTS: The way forward for rural development. Energy Sci. Eng. 2015, 3, 271-285. [CrossRef]

64. Hossain, S.; Jahid, A.; Islam, K.Z.; Rahman, F. Solar PV and Biomass Resources-Based Sustainable Energy Supply for Off-Grid Cellular Base Stations. IEEE Access 2020, 8, 53817-53840. [CrossRef] 
65. Xia, T.; Rezaei, M.; Dampage, U.; Alharbi, S.; Nasif, O.; Borowski, P.; Mohamed, M. Techno-Economic Assessment of a GridIndependent Hybrid Power Plant for Co-Supplying a Remote Micro-Community with Electricity and Hydrogen. Processes 2021, 9, 1375. [CrossRef]

66. Rezaei, M.; Dampage, U.; Das, B.K.; Nasif, O.; Borowski, P.F.; Mohamed, M.A. Investigating the Impact of Economic Uncertainty on Optimal Sizing of Grid-Independent Hybrid Renewable Energy Systems. Processes 2021, 9, 1468. [CrossRef]

67. Sanjay, K.C.; Karthikeyan, M.; Prasannakumaran, K.M.; Kirubakaran, V. Techno Commercial Study of Hybrid Systems for the Agriculture Farm Using Homer Software. In Hybrid Renewable Energy Systems; Wiley: Beverly, MA, USA, 2021 ; pp. 115-133. [CrossRef]

68. Shahzad, M.K.; Zahid, A.; Rashid, T.U.; Rehan, M.A.; Ali, M.; Ahmad, M. Techno-economic feasibility analysis of a solar-biomass off grid system for the electrification of remote rural areas in Pakistan using HOMER software. Renew. Energy 2017, 106, 264-273. [CrossRef]

69. Aziz, A.; Tajuddin, M.; Adzman, M.; Ramli, M.; Mekhilef, S. Energy Management and Optimization of a PV/Diesel/Battery Hybrid Energy System Using a Combined Dispatch Strategy. Sustainability 2019, 11, 683. [CrossRef]

70. Beitelmal, W.; Okonkwo, P.; Al Housni, F.; Alruqi, W.; Alruwaythi, O. Accessibility and Sustainability of Hybrid Energy Systems for a Cement Factory in Oman. Sustainability 2020, 13, 93. [CrossRef]

71. Chauhan, A.; Upadhyay, S.; Khan, M.; Hussain, S.; Ustun, T. Performance Investigation of a Solar Photovoltaic/Diesel Generator Based Hybrid System with Cycle Charging Strategy Using BBO Algorithm. Sustainability 2021, 13, 8048. [CrossRef]

72. Yadav, A.; Pal, N.; Bhukya, J. Design and development of PV-wind based hybrid renewable energy system. In Proceedings of the International Conference on Electronics and Sustainable Communication Systems, Coimbatore, India, 2-4 July 2020; pp. 1045-1051. [CrossRef]

73. Thirunavukkarasu, M.; Sawle, Y. Design, analysis and optimal sizing of standalone PV/diesel/battery hybrid energy system using HOMER. IOP Conf. Ser. Mater. Sci. Eng. 2020, 937, 12034. [CrossRef]

74. Ruelas, J.; Muñoz, F.; Lucero, B.; Palomares, J. PV Tracking Design Methodology Based on an Orientation Efficiency Chart. Appl. Sci. 2019, 9, 894. [CrossRef]

75. González-Peña, D.; García-Ruiz, I.; Díez-Mediavilla, M.; Dieste-Velasco, M.; Alonso-Tristán, C. Photovoltaic Prediction Software: Evaluation with Real Data from Northern Spain. Appl. Sci. 2021, 11, 5025. [CrossRef]

76. Seme, S.; Štumberger, B.; Hadžiselimović, M.; Sredenšek, K. Solar Photovoltaic Tracking Systems for Electricity Generation: A Review. Energies 2020, 13, 4224. [CrossRef]

77. Kuttybay, N.; Saymbetov, A.; Mekhilef, S.; Nurgaliyev, M.; Tukymbekov, D.; Dosymbetova, G.; Meiirkhanov, A.; Svanbayev, Y. Optimized Single-Axis Schedule Solar Tracker in Different Weather Conditions. Energies 2020, 13, 5226. [CrossRef]

78. Liu, Y.; Zhang, Y.; Zhao, Y.; Yue, H.; Gao, D.; Zhang, H.; Chen, H. Performance Comparison of Solar Single-Axis Tracking Low-Concentrating Photovoltaic/Thermal System with Different Axes. IEEE Access 2021, 9, 28632-28645. [CrossRef]

79. Fahad, H.M.; Islam, A.; Islam, M.; Hasan, F.; Brishty, W.F.; Rahman, M. Comparative Analysis of Dual and Single Axis Solar Tracking System Considering Cloud Cover. In Proceedings of the International Conference on Energy and Power Engineering (ICEPE), Dhaka, Bangladesh, 14-16 March 2019.

80. Al-Rousan, N.; Isa, N.A.M.; Desa, M.K.M. Advances in solar photovoltaic tracking systems: A review. Renew. Sustain. Energy Rev. 2018, 82, 2548-2569. [CrossRef]

81. Safieh, A.; Elnosh, A.; Kaiss, E.-C.A.K.; John, J.J.; Alnuaimi, A. Field Comparison Study of Fixed-Tilted and Single-Axis Tracking PV Structures in the Desert Environment of Dubai, UAE. In Proceedings of the 2020 47th IEEE Photovoltaic Specialists Conference (PVSC), Calgary, AB, Canada, 15 June-21 August 2020; pp. 2136-2139. [CrossRef]

82. Babatunde, O.M.; Munda, J.L.; Hamam, Y. Photovoltaic system sizing for household use: Effects of temperature, orientation and sun tracking. In Proceedings of the 2019 Open Innovations (OI), Cape town, South Africa, 2-4 October 2019; pp. 190-195. [CrossRef]

83. Campos, M.D.S.; Tiba, C. npTrack: A n-Position Single Axis Solar Tracker Model for Optimized Energy Collection. Energies 2021, 14, 925. [CrossRef]

84. Frydrychowicz-Jastrzębska, G.; Bugała, A. Solar Tracking System with New Hybrid Control in Energy Production Optimization from Photovoltaic Conversion for Polish Climatic Conditions. Energies 2021, 14, 2938. [CrossRef]

85. Hammoumi, A.E.; Motahhir, S.; Ghzizal, A.E.; Chalh, A.; Derouich, A. A simple and low-cost active dual-axis solar tracker. Energy Sci. Eng. 2018, 6, 607-620. [CrossRef]

86. Mpodi, E.K.; Tjiparuro, Z.; Matsebe, O. Review of dual axis solar tracking and development of its functional model. Procedia Manuf. 2019, 35, 580-588. [CrossRef]

87. Berrian, D.; Libal, J.; Klenk, M.; Nussbaumer, H.; Kopecek, R. Performance of Bifacial PV Arrays with Fixed Tilt and Horizontal Single-Axis Tracking: Comparison of Simulated and Measured Data. IEEE J. Photovolt. 2019, 9, 1583-1589. [CrossRef]

88. Mubaarak, S.; Zhang, D.; Chen, Y.; Liu, J.; Wang, L.; Yuan, R.; Wu, J.; Zhang, Y.; Li, M. Techno-Economic Analysis of GridConnected PV and Fuel Cell Hybrid System Using Different PV Tracking Techniques. Appl. Sci. 2020, 10, 8515. [CrossRef]

89. Alvarado-M, J.F.; Betancur, E.; Velasquez-Lopez, A. Optimization of Single-Axis Discrete Solar Tracking. In Proceedings of the 2020 9th International Conference on Renewable Energy Research and Application (ICRERA), Glasgow, UK, 27-30 September 2020; pp. 271-275. [CrossRef] 
90. Fuke, P.; Yadav, A.K.; Anil, I. Techno-Economic Analysis of Fixed, Single and Dual-Axis Tracking Solar PV System. In Proceedings of the 2020 IEEE 9th Power India International Conference (PIICON), Sonepat, India, 28 February-1 March 2020; pp. 1-6. [CrossRef]

91. Alexandru, C. Optimization of the Bi-Axial Tracking System for a Photovoltaic Platform. Energies 2021, 14, 535. [CrossRef]

92. Fathabadi, H. Novel Online Sensorless Dual-Axis Sun Tracker. IEEE/ASME Trans. Mechatronics 2016, 22, 321-328. [CrossRef]

93. Konneh, K.V.; Masrur, H.; Othman, M.L.; Wahab, N.I.A.; Hizam, H.; Islam, S.Z.; Crossley, P.; Senjyu, T. Optimal Design and Performance Analysis of a Hybrid Off-Grid Renewable Power System Considering Different Component Scheduling, PV Modules, and Solar Tracking Systems. IEEE Access 2021, 9, 64393-64413. [CrossRef]

94. Smirnov, A.A.; Malugin, S.A.; Bakanov, A.V. Designing Integrated PV Facility with Dual-Axis Solar Tracking System Mounted on the South Building Face. In Proceedings of the 2017 International Conference on Industrial Engineering, Applications and Manufacturing (ICIEAM), St. Petersburg, Russia, 16-19 May 2017; pp. 1-4. [CrossRef]

95. Pelaez, S.A.; Deline, C.; Greenberg, P.; Stein, J.S.; Kostuk, R.K. Model and Validation of Single-Axis Tracking with Bifacial PV. IEEE J. Photovolt. 2019, 9, 715-721. [CrossRef]

96. Rodriguez-Gallegos, C.D.; Gandhi, O.; Panda, S.K.; Reindl, T. On the PV Tracker Performance: Tracking the Sun Versus Tracking the Best Orientation. IEEE J. Photovolt. 2020, 10, 1474-1480. [CrossRef]

97. Saeedi, M.; Effatnejad, R. A New Design of Dual-Axis Solar Tracking System with LDR Sensors by Using the Wheatstone Bridge Circuit. IEEE Sens. J. 2021, 21, 14915-14922. [CrossRef]

98. Zaghba, L.; Khennane, M.; Borni, A.; Fezzani, A.; Bouchakour, A.; Mahammed, I.H.; Oudjana, S.H. An Enhancement of Grid Connected PV System Performance Based on ANFIS MPPT Control and Dual Axis Solar Tracking. In Proceedings of the 2019 1st International Conference on Sustainable Renewable Energy Systems and Applications (ICSRESA), Tebessa, Algeria, 4-5 December 2019; pp. 1-6. [CrossRef]

99. Lithium Battery Cost Have Fallen by $98 \%$ in Three Decades. Available online: https://www.economist.com/graphic-detail/2021 /03/31/lithium-battery-costs-have-fallen-by-98-in-three-decades (accessed on 16 June 2021). 